\title{
Anti-quality factors associated with alkaloids in eastern temperate pasture
}

\author{
F.N. THOMPSON, J.A. STUEDEMANN, AND N.S. HILL
}

Authors are professor emeritus of physiology, College of Veterinary Medicine University of Georgia, Athens, Ga 30602, animal scientist, J.Phil Campbell, Sr., Natural Resource Conservation Center, USDA-ARS, Watkinsville, Ga 30677 and professor Department of Crop and Soil Sciences, University of Georgia, Athens, Ga 30602.

\begin{abstract}
The greatest anti-quality associated with eastern temperature pasture grasses is the result of ergot alkaloids found in endophyte-infected (Neotyphodium ceonophialum) tall fescue (Festuca arundinacea Schreb.) The relationship between the grass and the endophyte is mutalistic with greater persistence and herbage mass as a result of the endophyte. Ergot alkaloids reduce growth rate, lactation, and reproduction in livestock. Significant effects are the result of elevated body temperature and reduced peripheral blood flow such that necrosis may result. Perturbations also occur in a variety of body systems. Planting new pastures with seed containing a "non-toxic" endophyte appears to be a potential solution. Ergotism results from the ingestion of the scelerotia of Claviceps purpurea containing ergot alkaloids found on seed heads. Ergotism resembles the effects of endophyte-infected tall fescue. Endophyte-infected perennial ryegrass (Lolium perenne L.) contains ergot and lotirem alkaloids that result in reduced growth and tremors. Reed canarygrass (Phalaris Anundinacba L.) contains tryptamine, hordenine and gramine alkaloids that reduce growth. Annual ryegrass (Lolium multiplorum L. may contain galls with cornetoxins which result in neurological signs.
\end{abstract}

Key Words: tall fescue, ergotism, perennial ryegrass, reed canarygrass, annual ryegrass

The term "eastern temperature grass" is somewhat subjective and could be defined to include any grass species grown in temperate zones or species that originate and predominate within the temperate regions of the world. Numerous grass species contain anti-quality compounds as defense mechanisms, so this discussion will be limited to grasses that are utilized in the eastern half of the United States, have origins in temperature climatic regimes, and contain the $\mathrm{C}_{3}$ photosynthetic pathway common to cool-season grasses. Using this definition of the term, this discussion will focus on 2 grass species, i.e., tall fescue (Festuca arundinacea Schreb.) and perennial ryegrass (Lolium perenne L.) that form mutualistic associations with other organisms resulting in anti-quality products, and 1 grass species, reed canarygrass (Phalaris anundinacea L.), in which anti-quality products are an endemic function of the plant genome. In addition, ergotism and annual ryegrass (Lolium multiflorum L.) toxicosis are the result of organisms parasitizing forages.

\footnotetext{
Manuscript accepted 24 Mar. 01
}

\section{Resumen}

El principal factor anti-calidad asociado con los de zacates templados del este que se utilizan para praderas es el resultado de los alcaloides Ergot encontrados en el pasto Alta fescue infectado de hongo endófito (Neotyphodium ceonophialum). La relación entre el pasto y el endófito es mutualista, con mayor persistencia y masa de forraje como resultado del endófito. Los alcaloides Ergot reducen la tasa de crecimiento, la lactación y la reproducción del ganado. Los efectos críticos son el resultado de la elevada temperatura corporal y el reducido flujo periférico de sangre que puede ocasionar en necrosis. También ocurren perturbaciones en una variedad de sistemas corporales. El plantar praderas nuevas con semilla libre del hongo endófito parece ser una solución potencial El Ergotismo resulta de la ingestión de la esclerotia de Claviceps purpuerea que contiene alcaloides Ergot la cual se encuentra en las estructuras de la planta que contienen las semillas. El Ergotismo asemeja los efectos producidos por el zacate Alta fescue infectado por el hongo endófito. El ryegrass perenne infectado con el endófito contiene alcaloides ergot y lotirem que resultan en un crecimiento reducido y temblores. El zacate "Reed canarygrass" contiene los alcaloides triptamina, hordenina y gramina los cuales reducen el crecimiento. El rye grass anual puede contener agallas con cornetoxinas las cuales resultan en síntomas necrológicos.

\section{Tall Fescue}

The most notorious grass-related livestock anomaly in the United States is fescue toxicosis, affecting over 8.5 million beef cows and 700,000 horses (Ball et al. 1996). The economic impact of grazing endophyte-infected $(\mathrm{E}+)$ tall fescue upon the beef industry has been estimated to exceed $\$ 700$ million per annum (Hoveland 1990). Further economic impacts occur upon the horse and sheep industry. The agronomic attributes of tall fescue (Festuca arundinacea Schreb.) make it an attractive forage species because of its ability to withstand drought, poor soil conditions, and intensive defoliation from grazing. It is utilized on approximately 14 million hectares of pasture and hayfields, most of which are located in the eastern half of the United States. Fescue toxicosis occurs when the plant is infected with the constitutive clavicipitaceous endophytic fungus, Neotyphodium coenophialum (Glenn et al. 1996, formerly called Acremonium). The endophyte lives in intercellular spaces of sheath, stem, leaf, and seed tissues. There is no invasion of plant cells nor does the endophyte become pathogenic. It is passed from generation to generation via seed, so infected plants beget infected 
offspring and thus perpetuate the association. In a survey of over 1500 pasture samples obtained throughout the United States, more than $70 \%$ of the samples had $60 \%$ or more endophyte infection rates (Shelby and Dalrymple 1987). Seeds which were tested generally had the same rate of presence as pasture samples, but nearly $90 \%$ of the seed samples had less than $20 \%$ viable (living) endophyte. The obvious question then is, "Why are fields highly infected if the endophyte does not survive in the seed from which they were planted?" Older tall fescue stands are typically highly infected because in mixed stands of endophyte-free (E-) and E+ plants, E+ plants choke out and replace the E- plants and hence, pastures convert from low-infection rates to high-infection rates as the process continues.

The grass benefits from the endophytegrass association in part by a group of infected tall fescue has greater forage and

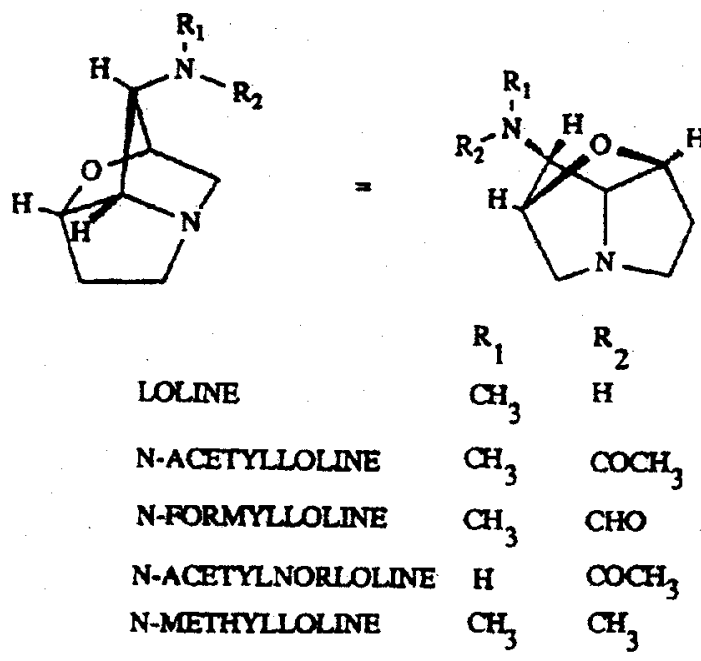

Fig. 2. Loline alkaloids found in endophyte-infected tall fescue (Porter 1994). alkaloids produced by the endophyte or by the plant in response to the endophyte. Ergot (Fig. 1) and clavine alkaloids, peramine, and saturated aminopyrrolizidine (lolines) alkaloids (Fig. 2) are all biologically active compounds that serve as feeding deterrents and decrease reproduction and growth by both mammals (Porter 1994, Stuedemann et al. 1989) and insects (Clay et al. 1985, Clay 1989, Siegel et al. 1991, Porter 1994). Protection from defoliation suggests solar energy capture and retention is a paramount priority in this association. Reduced insect or livestock grazing results in more photosynthetically active leaf area, resulting in greater energy capture, greater energy reserves, and greater regrowth capacity when infected with the endophyte (Hill et al. 1990). Endophyteseed productivity than the E- form (Hill et al. 1991) and is more drought tolerant (West et al. 1993).
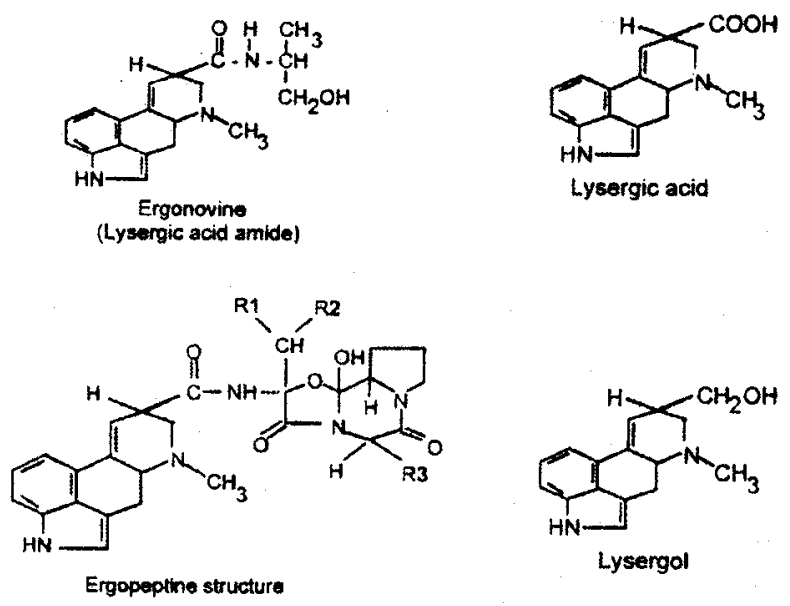

Fig. 1. Ergot alkaloids found in endophyte-infected tall fescue (Porter 1994).

The endophyte receives a home and a food supply in return for its contribution to the plant. This means the endophyte is never subjected to environmental forces and is only dependent upon plant health for its survival (Hill 1994). Hence, it is in the plant's interest to provide the needs for the endophyte; and the endophyte to provide protection to the plant against climatic and biological forces (e.g., insects) that may be threatening.

\section{Animal Toxicosis-Tall Fescue}

The impact or effects of consumption of E+ tall fescue have been reviewed (Bush et al. 1979, Stuedemann and Hoveland 1988, Schmidt and Osborn 1993, Stuedemann and Thompson 1993). Readers are referred to those reviews for specific information on the impact of E+ tall fescue on animal response. A compendium of the effects of the endophyte on animal response variables is presented in Tables 1 (performance and production), 2

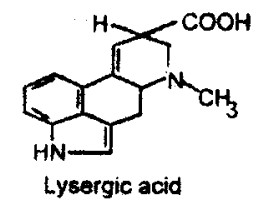

(animal behavior), 3 (physiological) and 4 (sera or plasma). In cases where extensive data exist, only a few selected articles were referenced to illustrate effects.

The presence of ergot and perhaps other alkaloids in forage resulting in depressed body weight gains in livestock grazing E+ tall fescue particularly during the warm season is often referred to as summer fescue toxicosis. Affected animals have an unthrifty appearance, long rough hair coats, excessive salivation and elevated respiratory rates and spend less time grazing during daylight hours (Stuedemann and Hoveland 1988). Calving rates are also decreased (Porter and Thompson 1992) as well as milk yield in dairy cows (Strahan et al. 1987). Fescue foot and fat necrosis are 2 other conditions in cattle associated with E+ tall fescue. Fescue foot is a gangrenous condition of the hooves, tail and occasionally ears that occurs primarily during the winter months (Yates 1983). Fat necrosis occurs in mature cows and is associated with masses of hard fat in the abdomen, leading to poor digestion and calving problems (Bush et al. 1979). We postulate that both fat necrosis and fescue foot are symptoms of fescue toxicosis.

Milk Production and Calf Growth. Milk production was reduced as much as $60 \%$ in dairy cows consuming an E+ ryegrasstall fescue hybrid compared to the same Ehybrid (Hemken et al. 1979). There was also an associated decrease in forage intake. In a subsequent study daily milk production was significantly reduced in mid-lactation Holsteins on E+ compared to E- tall fescue (Strahan et al. 1987). There was also an associated significant decrease in daily dry matter intake on E+ $(7.1 \mathrm{~kg})$ compared to E- $(9.1 \mathrm{~kg})$ tall fes- 
Table 1. Effects of endophyte-infected fescue on animal performance criteria.

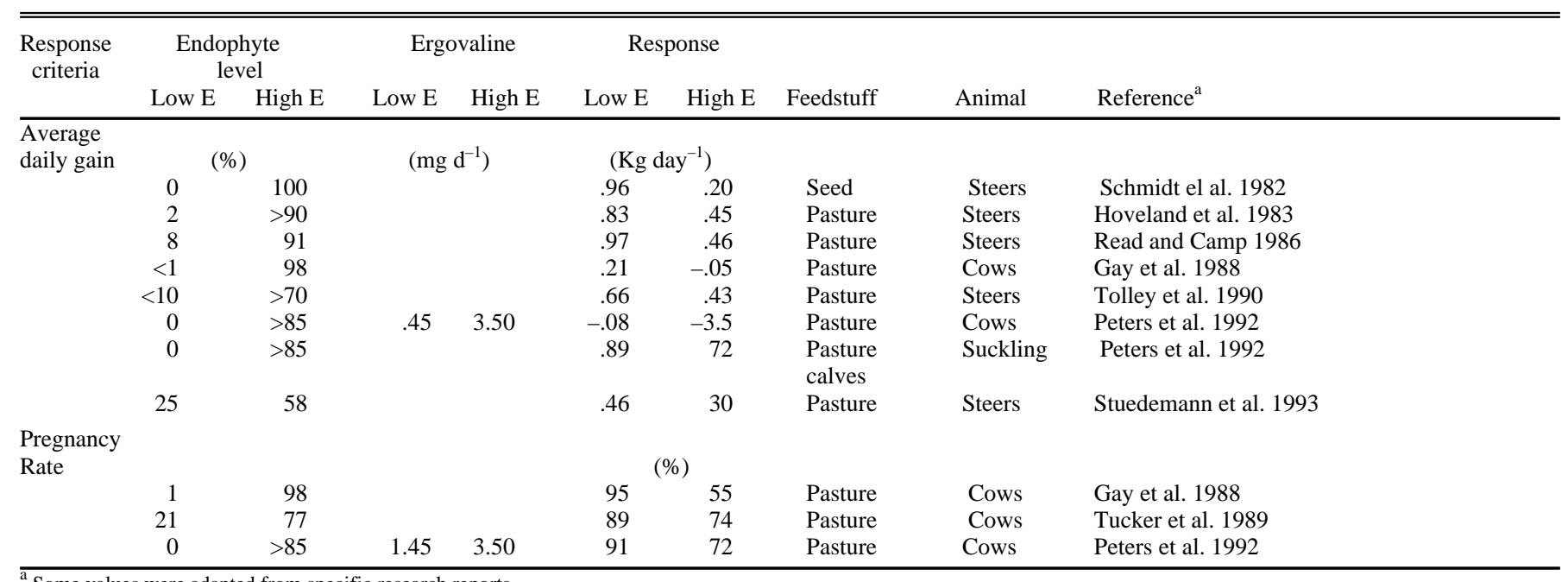

${ }^{\mathrm{a}}$ Some values were adapted from specific research reports.

cue. Cows receiving E- tall fescue gained $12.0 \mathrm{~kg}$ during the experiment compared to a weight loss $(-11.7 \mathrm{~kg})$ in cows fed E+ tall fescue. The authors suggested that there was no endophyte threshold level below which milk production in dairy cows would not be adversely affected.

Milk production was $75 \%$ greater in beef cows grazing E- compared to E+ tall fescue (Schmidt et al. 1984). At 100 days postpartum, primiparous beef cows grazing E+ tall fescue had 50\% lower milk production than those grazing E- tall fescue (Schmidt et al. 1986). Beef cows grazing E+ KY 31 tall fescue had a $25 \%$ reduction in milk production compared to cows grazing E- Mozark tall fescue or orchard grass, $(6.0$ and $8.0 \mathrm{~kg} /$ day, respectively) (Peters et al. 1992). Calf growth associated with nursing cows grazing E+ tall fescue was also significantly reduced compared to the other 2 groups. A similar reduction in calf weights associated with nursing cows grazing E+ tall fescue was reported by Gay et al. (1988). These effects of $\mathrm{E}+$ tall fescue are most detrimental to calf-weaning weights considering that cow-milk production accounts for approximately $66 \%$ of the variance in calfweaning weight. In this regard Danilson et al. (1986) calculated a $0.15 \mathrm{~kg}$ reduction in milk production for each $10 \%$ increase in pasture endophyte-infection level. Grazing E+ tall fescue also reduced milk production in ewes (Stidham et al. 1982).

The effect of grazing E+ tall fescue on calf-birth weight either had no effect (Schmidt et al. 1986) or there was a reduction in birth weight (Bolt and Bond 1989).

Reproduction in Beef Cattle. This subject has been reviewed (Porter and Thompson 1992, Schmidt and Osborn 1993). In studies summarized by Schmidt and Osborn (1993), lactating beef cows grazing E+ tall fescue both lost weight and had reduced pregnancy rates compared to cows grazing E- tall fescue. A decline in cow body condition postpartum negatively affects reproduction and results in a prolonged interval from parturition to first estrus (Wiltbank et al. 1964). In a 3-yr cow study Gay et al. (1988) reported calving rates were 95 and $55 \%$ for the E- and E+ tall fescue groups, respectively. In another 3-yr study Washburn and Green (1991) reported that $65 \%$ and $39 \%$ of cows on low vs. high endophyte, respectively, raised a calf each year. Similarly, Boling (1985) reported cows grazing lowendophyte infected Kenhy tall fescue had calving rates of $86 \%$ compared to $67 \%$ for E+ tall fescue.

A greater negative effect from grazing E+ tall fescue upon reproduction occurred in beef heifers compared to cows. Heifers raised on E+ tall fescue had delayed onset

Table 2. Effects of endophyte-infected tall fescue on behavioral response criteria.

\begin{tabular}{|c|c|c|c|c|c|c|c|c|c|}
\hline \multirow[t]{2}{*}{$\begin{array}{c}\text { Response } \\
\text { criteria }\end{array}$} & \multicolumn{2}{|c|}{$\begin{array}{c}\text { Endophyte } \\
\text { level }\end{array}$} & \multicolumn{2}{|c|}{ Ergovaline } & \multicolumn{2}{|c|}{ Response } & \multirow[b]{2}{*}{ Feedstuff } & \multirow[b]{2}{*}{ Animal } & \multirow[b]{2}{*}{ Reference $^{\mathrm{a}}$} \\
\hline & Low E & High E & Low $\mathrm{E}$ & High E & Low $\mathrm{E}$ & High E & & & \\
\hline \multirow[t]{6}{*}{ Intake } & & $\%)$ & & $\mathrm{Kg} \mathrm{day}^{-1}$ & & & & & \\
\hline & 0.0 & 100 & & & 6.6 & 4.2 & Pasture & Steers & Stuedemann et al. 1989 \\
\hline & 0.0 & 96 & \multicolumn{2}{|c|}{$(\mathrm{mg} / \mathrm{d})$} & $\begin{array}{l}6.0 \\
(\% \mathrm{c}\end{array}$ & $\begin{array}{l}3.2 \\
3 W)\end{array}$ & Seed & Steers & Osborn et al. 1992 \\
\hline & 0.0 & $>85$ & 1.45 & 3.50 & 2.40 & 2.25 & Pasture & Cows & Peters et al. 1992 \\
\hline & & & \multicolumn{2}{|c|}{$\left(\mathrm{mg} / \mathrm{kg} \mathrm{BW}{ }^{.75}\right)$} & & & & & \\
\hline & & & 0.0 & 0.053 & 2.55 & 1.76 & $\begin{array}{l}\text { Seed } \\
\& \text { hay }\end{array}$ & Sheep & Aldrich et al. 1993b \\
\hline \multirow{3}{*}{$\begin{array}{l}\text { Water } \\
\text { intake }\end{array}$} & & & \multicolumn{6}{|c|}{$\left(\right.$ Lis in day $\left.{ }^{-1}\right)$} & \\
\hline & & & 0.0 & 0.053 & 4.2 & 5.3 & $\begin{array}{l}\text { Seed } \\
\& \text { hay }\end{array}$ & Sheep & Aldrich et al. 1993b \\
\hline & & & 0.0 & 0.05 & 49.3 & 48.9 & Seed & Heifers & Aldrich et al. $1993 b$ \\
\hline
\end{tabular}


Table 3. Effects of endophyte-infected fescue on physiological response criteria.

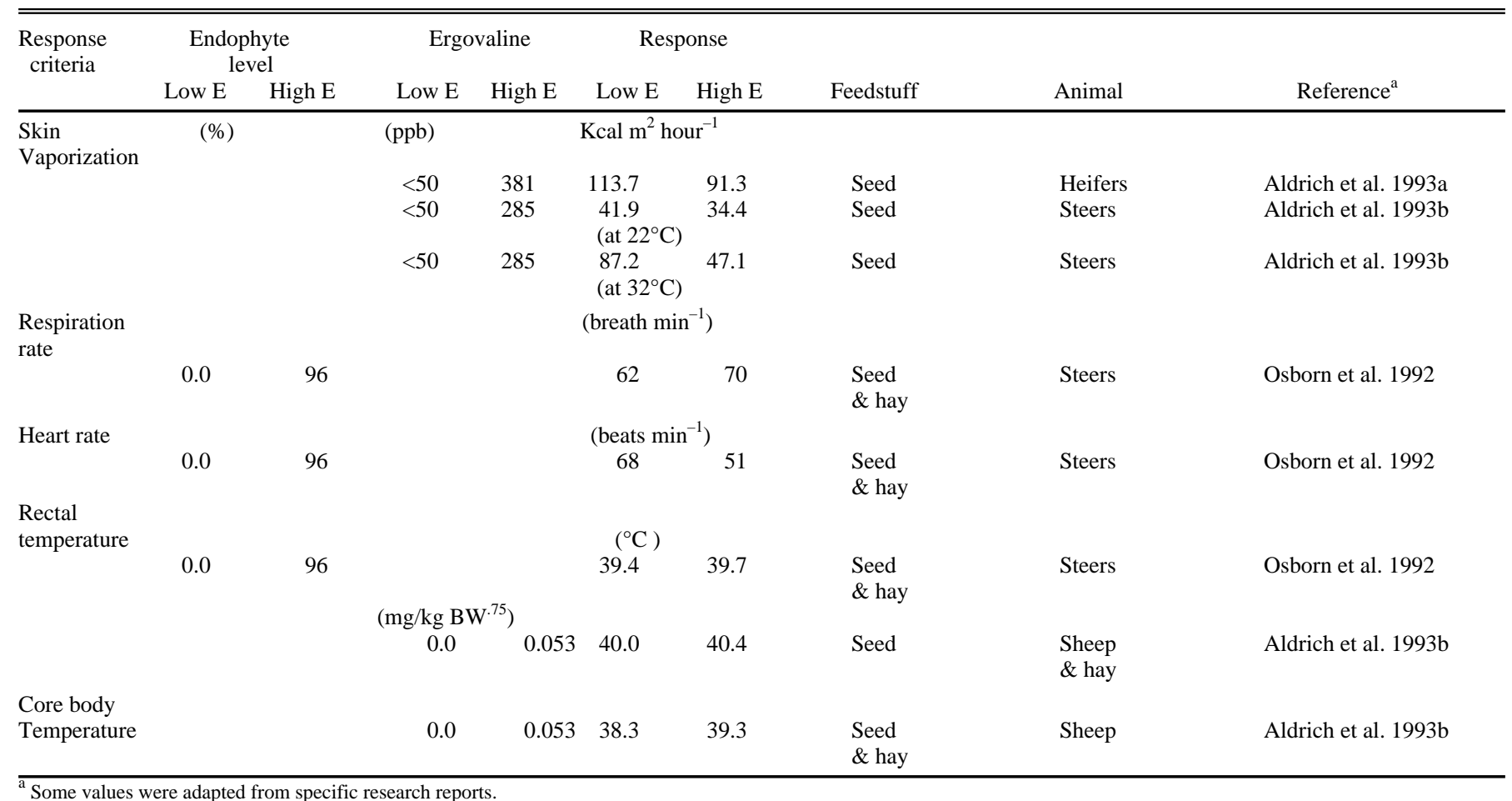

${ }^{\mathrm{a}}$ Some values were adapted from specific research reports.

of puberty and decreased first-service conception rates (Washburn et al. 1989). Similarly, in another study there was a $96 \%$ conception rate in beef heifers raised on E- tall fescue compared to a conception rate of $55 \%$ on $\mathrm{E}+$ tall fescue (Schmidt et al. 1986). In the following year, only $33 \%$ of the then primiparous cows grazing E+ tall fescue were successfully rebred compared to $93 \%$ on E- tall fescue.

The adverse effect of the endophyte upon reproduction in cattle is mediated partially at least, by increased early embryonic mortality. Cattle embryos transferred into heifers grazing $\mathrm{E}+$ tall fescue had decreased survival compared to embryos transferred into heifers grazing E- tall fescue (Rahe et al. 1991). Similarly, cattle embryos taken from cows grazing $\mathrm{E}+$ tall fescue had decreased in vitro cleavage, rate of development and quality compared to those from cows grazing Etall fescue (Nasti et al. 1994).

Impact on Horses. The pregnant mare is very sensitive to the effects of grazing $\mathrm{E}+$ tall fescue (Cross 1997). Mean gestation length in mares consuming $\mathrm{E}+$ tall fescue was lengthened 27 days (Monroe et al. 1988). Others reported similar effects (Putnam et al. 1991, Redmond et al. 1994). Severe dystocia frequently occurs with prolonged gestation in mares on E+ tall fescue. Putnam et al. (1991) reported that 10 of 11 mares grazing E+ tall fescue experienced dystocia. Supplementing pregnant mares on $\mathrm{E}+$ tall fescue with shelled corn had no effect on gestation length or incidence of dystocia (Earle et al. 1990). Placentas from affected mares were thickened, reddish colored and heav-

ier (Monroe et al. 1988, Brendemuehl et al. 1994b). Surviving foals were largeframed and emaciated in appearance, with premature eruption of teeth and overgrown hooves (Monroe et al. 1988, Putnam et al. 1991). Mares should be removed from E+

Table 4. Effect of ingestion of endophyte-infected tall fescue on sera or plasma constituents of cattle.

\begin{tabular}{lll}
\hline \hline Response criteria & Direction Reference & \\
\hline Alkaline phosphatase & reduced & Bond et al. 1984 \\
& & Boling et al. 1989 \\
Amylase & increased & Nutting et al. 1992 \\
Asparatate aminotransferase & reduced & Dougherty et al. 1991 \\
Cholesterol & reduced & Bond et al. 1984 \\
& & Stuedemann et al. 1985a \\
& & Lipham et al. 1989 \\
Cortisol & & Tolley et al. 1990 \\
Creatine kinase & unchanged & Aldrich et al. 1993a \\
Growth hormone & reduced & Dougherty et al. 1991 \\
& unchanged & Elsasser and Bolt, 1987 \\
Insulin-like growth factor & & Lipham et al. 1989 \\
Lactic dehydrogenase & increased & Thompson et al. 1987 \\
Luteinizing hormone & reduced & Filipov et al. 1999 \\
Melatonin & reduced & Dougherty et al. 1991 \\
Prolactin & unchanged & Mizinga et al. 1992 \\
& reduced & Hurley et al. 1981 \\
Thyroid stimulating hormone & decreased & Porter et al. 1990 \\
Thyodhyronine & & Hurley et al. 1981 \\
\hline & & Elsasser and Bolt, 1987
\end{tabular}


tall fescue at least 30 days prior to expected foaling (Taylor 1993).

Following foal delivery mares grazing E+ tall fescue had a high incidence of either agalactia or reduced milk yield (Monroe et al. 1988, Putnam et al. 1991). The milk from such mares was off-colored (straw-colored with an oily appearance), rather than the white milk of normal mares. This milk lacked normal immunoglobulin concentrations and, consequently, foals did not have normal passive immunity (Cross 1997).

Grazing E+ tall fescue alters the reproductive endocrinology of the pregnant mare (reviewed by Cross 1997). Serum concentrations of the pituitary hormone, prolactin, that is necessary for the onset of lactation (lactogenesis) were depressed. Serum progesterone concentrations were also lowered, but serum concentrations of estradiol were increased. This indicates that placental function is altered because progesterone and estradiol are secreted from that organ.

Grazing E+ tall fescue did not increase body temperature in horses (Monroe et al. 1988), perhaps because of the ability of horses to dissipate heat by sweating. Putnam et al. (1991) observed increased sweating in pregnant mares grazing $\mathrm{E}+$ tall fescue. A relationship between grazing E+ tall fescue and laminitis has been suggested based upon epidemiologic and pathologic reports (Rhorbach et al. 1995). McCann et al. (1992a) reported no reduction in growth of yearling horses grazing E+ tall fescue supplemented with concentrate. In contrast, average daily gain was reduced by $57 \%$ in yearling horses grazing $\mathrm{E}+$ tall fescue without supplementation (Aiken et al. 1993). Relative to mare fertility (Brendemuehl et al. 1994a) reported that mares grazing E+ tall fescue had reduced fertility and increased early embryonic mortality rates.

Behavior, Intake and Digestibility. During daylight, cattle on E+ tall fescue pastures spent less time grazing (Stuedemann et al. 1985b, Lipham et al. 1989). In sunlight, steers on E+ tall fescue grazed $5-21 \%$ of the time between 1200 and 1600 hours compared to $43-65 \%$ for steers grazing E- tall fescue (Stuedemann et al. 1985b). This effect persisted for at least 26 days after the steers were moved from $\mathrm{E}+$ to $\mathrm{E}$ - pastures. There is no known explanation for this residual behavior.

Much of the reduction in animal performance has been attributed to reduced intake. The presence of the endophyte reduced intake in cattle (Hemken et al. 1981, Schmidt et al. 1982, Stuedemann et al. 1989, Osborn et al. 1992) and sheep (Hemken et al. 1979, Aldrich et al. 1989). An $8 \%$ depression in intake in steers fed E+ tall fescue hay resulted in a $58 \%$ suppression in average daily gains (Schmidt et al. 1982). Steers grazing E- tall fescue had a $43-69 \%$ greater dry matter intake compared to steers on E+ tall fescue (Stuedemann et al. 1989).

While the negative effect of the endophyte upon intake may due to palatability or secondarily to increased body temperature (Beede and Collier 1986), a separate neural mechanism is probable. Metoclopramide, primarily a dopaminergic antagonist with some anti-serotinergic activity (Freeman et al. 1992), increased intake in lambs held at $32^{\circ} \mathrm{C}$ fed a high endophyte diet with no alteration in body temperature (Aldrich et al. 1989).

The effect of E+ tall fescue on intake is exacerbated by elevated environmental temperatures (Hemken et al. 1981). When calf intake of E+ and E- tall fescue forage was compared in environmental chambers, the $\mathrm{E}+$ forage decreased intake only when environmental temperatures exceeded $31^{\circ} \mathrm{C}$. In a similar experiment with calves in environmental chambers at $21^{\circ} \mathrm{C}$ and $32^{\circ} \mathrm{C}$, and fed an endophyte-free tall fescue diet with added ergotamine resulted in reduced intake at both temperatures (Osborn et al. 1992).

In vitro dry matter digestibility was superior for E+ hay compared to E- tall fescue hay (Schmidt et al. 1982). Chestnut et al. (1991) found no difference in organic matter digestibility of E+ and E- tall fescue in steers and Harmon et al. (1991) found no endophyte effect on dry matter and nitrogen digestibility in steers. Others, however, found that diets containing E+ tall fescue had reduced dry matter and organic matter digestibility in sheep (Hannah et al. 1990, Fiorito et al. 1991, Westendorf et al. 1993), cattle (Aldrich et al. 1993a), and rats (Larson et al. 1991), which could be ambient temperaturedependent (Hannah et al. 1990).

A metabolic cost has been associated with the endophyte. This was revealed by pair-fed experiments where the intake of animals receiving E- diet was maintained at the intake level of the $\mathrm{E}+$ tall fescue seed-based diet group. Using this strategy with rats and cows, a depression in body weight gains occurred in the animals receiving E+ diets (Mizinga et al. 1992, 1993). Therefore, growth in rats and cattle are affected by the endophyte in some manner beyond intake. This could be due to increased hepatic mixed function oxidase activity related to detoxification as found in sheep on E+ diets (Zanzalari et al. 1989).

Body Temperature, Respiratory and Heart Rates. Inclusion of the endophyte in fed diets has resulted in increased rectal temperature and respiratory rate. In this regard, the effects of the endophyte were investigated using temperature controlled rooms (Hemken et al. 1981, Rhodes et al. 1991, Osborn et al. 1992, Aldrich et al. 1993b, Cornell et al. 1990). Calves consuming a toxic ryegrass-tall fescue hybrid at increased ambient temperatures had increased rectal temperatures, respiratory rates and depressed body weight gains compared to those fed a non-toxic hybrid (Hemken et al. 1981); however, at lower ambient temperatures there were no differences in respiratory rate and rectal temperatures. In a later experiment using steers fed E-, E+ or E- diets plus ergotamine at both a thermoneutral temperature $\left(21^{\circ} \mathrm{C}\right)$ and a heat stressed environment $\left(32^{\circ} \mathrm{C}\right)$, Osborn et al. (1992) reported both temperature and endophyte increased rectal temperature and decreased heart rate, but no significant interaction occurred between endophyte and temperature. Respiratory rate was increased with the endophyte only at the elevated temperature. Ergotamine induced changes similar to those found by feeding E+ diets. Both the endophyte and added ergotamine decreased peripheral body temperature; this was attributed to reduced peripheral blood flow. Similar changes in rectal temperature in cattle resulted from feeding E+ or E- tall fescue diets when animals were exposed to diurnal temperature changes (Aldrich et al. 1993a). Interestingly, this experiment also revealed that there was a significant interaction between diet and environmental temperature on skin vaporization; with skin vaporization increased only in the E- group at an elevated temperature. Therefore the effect of the endophyte reduces the ability to remove excess body heat. A relationship was established between dietary ergovaline concentrations fed to cattle and rectal temperatures (Cornell et al. 1990). Ergovaline at 50 ppb, lowest concentration, resulted in increased rectal temperature only at $30^{\circ} \mathrm{C}$ ambient temperature and above.

Ergot alkaloids can increase body temperature by a direct effect upon the temperature regulating areas in the brain (Nickerson 1970, Loew et al. 1978). This central effect upon body temperature occurs at a lower dosage compared to that necessary to mediate vasoconstriction. Spiers et al. (1995) investigated the effects of injecting rats with ergovaline in both a 
cold environment $\left(7-9^{\circ} \mathrm{C}\right)$ and hot environment $\left(31-33^{\circ} \mathrm{C}\right)$. Treatment in the cold environment resulted in a decrease in both rectal and tail temperature whereas treatment in the hot environment resulted in an elevation of rectal temperature, but a reduction in tail temperature.

The effects of ergot alkaloids are complicated as they are adrenergic and dopaminergic agonists as well as both serotinergic agonists and antagonists (Muller-Schweintzer and Weidmann 1978). Receptors for these activities are widely dispersed. In this regard treatment of previously dewormed heifers fed E+ diets treated with ivermectin, an anthelmintic that binds to g-amino butyric neural receptors (Barragry 1984), had reduced core body temperature and increased intake upon heat exposure (Dr. Spiers, University of Missouri, personal communication). Treatment of cattle grazing $\mathrm{E}+$ tall fescue with ivermectin topically before grazing and again at 56 days after beginning the experiment had increased weight gains (Bransby 1997). In some experiments this treatment resulted in increased gains in cattle on E- tall fescue in spite of very low fecal egg counts. Therefore, while ivermectin resulted in a positive effect in cattle on $\mathrm{E}+$ tall fescue, this effect may not have a specific effect against alkaloids in the forage. Interestingly, a combination of an anabolic ear implant containing estradiol and progesterone plus ivermectin to cattle overcame the growth depressant effect of E+ tall fescue.

Vasoconstriction. In vitro ergot alkaloids mediated vasoconstriction of bovine dorsal pedal veins via $\alpha-2$ adrenergic properties (Solomons et al. 1989). Nacetyl loline had some effect in this regard (Oliver et al. 1990). A subsequent study (Dr. Jack Oliver, University of Tennessee, personal communication) demonstrated extreme potency of ergovaline in this regard. Most interestingly, Oliver et al. (1998) demonstrated that venous preparations from cattle on $\mathrm{E}+$ diets had an enhanced contractility to an alpha-2 adrenergic agonist. Dyer (1993) reported ergot alkaloids mediated vasoconstriction upon cattle uterine and umbilical veins via a serotinergic mechanism.

Vasoconstriction is important in the pathogenesis of fescue foot. Yates et al. (1979) showed that administration of toxic anion fractions from fescue resulted in decreased coronary band temperatures in cattle. Decreased blood flow to the digit would result in decreased nutrient delivery and tissue death. A mechanism for the vasoconstriction is found in the thickening of the smooth muscle layer of the arterioles in cattle following ingestion of the endophyte (Oliver and Schultze 1997). In this regard bovine vascular smooth muscle proliferated in vitro in response to both ergot alkaloids and $\mathrm{N}$-acetyl loloine (Strickland et al. 1996).

Prolactin, Neural Function and Hair Coat. Serum prolactin is reduced in livestock species consuming E+ diets (Hurley et al. 1981, Bolt et al. 1983, Thompson et al. 1987, Lipham et al. 1989, McCann et al. 1992b). Pituitary secretion of prolactin is inhibited by dopamine and ergot alkaloids are potent dopaminergic agents (Lamberts and Macleod 1990). Ergot alkaloids were ranked relative to competitive binding to dopamine receptors on pituitary cells (Larson 1997). Ergovaline shared potency with other ergopeptines in this regard and the ergopeptine alkaloids had 10 -fold greater activity compared to ergine and ergonovine.

Depressed serum prolactin with E+ diets indicates an impact of ergot alkaloids on both pituitary and neural function. While prolactin is required for the onset of lactation, it is not importantly related to growth (Eisemann et al. 1984). The central nervous system and pituitary have an abundance of dopamine receptors. Metoclopramide (dopamine antagonist) given to steers grazing E+ tall fescue increased serum prolactin, improved hair coat quality, body weight gains and more time was spent grazing (Lipham et al. 1989). The dull and shaggy hair coat changes associated with fescue toxicosis may also result from depressed serum prolactin. Administration of prolactin to hamsters following pituitary removal resulted in hair changes appropriate for the photoperiod under which they were maintained (Niklowitz and Hoffmann 1988). In sheep, increased daylight length that results in increased serum prolactin, which is importantly related to a spring moult and production of a summer coat (Lincoln 1990). As a specific cellular mechanism upon neural function, ergovaline inhibited $\mathrm{Na}+/ \mathrm{K}+$ ATPase activity in a dose dependent manner in rat brain homogenates (Moubarak et al. 1993).

Hepatic/Insulin-Like Growth Factor/Energy Production. The major anabolic effect of growth hormone (GH) secreted from the pituitary is expressed via stimulating secretion of insulin-like growth factor-1 (IGF) prominently from the liver (Hossner et al. 1997). Secretion of IGF is modulated by diet and intake (Elsasser et al. 1989). Circulating IGF has a negative effect upon GH secretion. The effects of $\mathrm{E}+$ tall fescue intake on serum GH have been variable (Oliver 1997). Both ergotamine and ergonovine elevated plasma $\mathrm{GH}$ in steers (Browning et al. 1997). Serum IGF was reduced in steers grazing E+ tall fescue (Filipov et al.1999, Hazlett et al. 1998 ), suggesting this may be an important mechanistic effect whereby the ergot alkaloids suppress growth.

Ergot alkaloids may also alter energy metabolism and electrolyte movement in the liver, as both ergonovine and ergotamine inhibited $\mathrm{Ca}^{2++}$-activated bovine mitochondrial ATPase activity (Moubarak et al. 1998). As previously mentioned, E+ intake increased mixed function oxidases in the liver of sheep (Zanzalari et al. 1989).

Fat Metabolism. Serum cholesterol is reduced by grazing $\mathrm{E}+$ tall fescue in cattle (Stuedemann et al. 1985a, Lipham et al. 1989) and sheep (Bond et al. 1988). It is unknown whether this was the result of increased cholesterol uptake by the tissues or decreased hepatic secretion. The ergot alkaloids may decrease lipolysis by an adrenergic receptor activity in the liver (Oliver 1997). An association was made between high-nitrogen fertilization of E+ tall fescue, reduced serum cholesterol and the incidence of fat necrosis in cattle (Stuedemann et al. 1985a). Serum triglyceride levels were also reported to be decreased in cattle on E+ diets (Oliver 1997). Together these studies indicate that ingestion of E+ diets alters lipid metabolism.

Serum Enzymes. Several serum enzymes, alkaline phosphatase, aspartate amino transferase, alanine amino transferase, and lactic dehydrogenase, are frequently reduced in cattle on $\mathrm{E}+$ diets (reviewed by Stuedemann and Thompson 1993, Oliver 1997). This general decrease in enzymatic activity by $\mathrm{E}+$ diets has been attributed to increased hepatic $\alpha-2$ adrenergic activity (Oliver 1997). Other possible mechanisms include inhibitors of enzymatic action, effects on cell proliferation, increased clearance via the liver or kidney, loss of enzymatic cofactors and alterations in conditions that might inhibit enzymatic action, e.g. $\mathrm{pH}$ and tonicity (Schultze et al. 1999). Dougherty et al. (1991) reported that circulating gamma glutamyltransferase, as well as aspartate aminotransferase and creatinine kinase were reduced in cows fed E+ tall fescue seed. Gamma glutamyltransferase is produced specifically in the liver in the bovine species (Duncan et al. 1994). It is pertinent to recognize that only an increase in the circulating concentration of 
these enzymes is an indication of inflammation of the organ(s) of origin.

The reduction of alkaline phosphatase as the result of $\mathrm{E}+$ diets is rather consistently observed (Bond et al. 1984, Boling et al. 1989, Jackson et al. 1997, Gould and Hohenboken 1993, Schultze et al. 1999). A steady decrease in the concentration of alkaline phosphatase was observed in steers grazing E+ tall fescue (Schultze et al. 1999). This enzyme catalyzes the hydrolysis of monophosphate esters under alkaline conditions (Duncan et al. 1994). Quantitative isoenzyme determinations of this enzyme obtained from cattle grazing E+ indicated that the decrease in this enzyme was due to lowered activities of intestinal and bone isoenzymes (Schultze et al. 1999). Therefore, an effect upon serum enzymes extends beyond the liver.

Copper Status. Consumption of presumably high-endophyte tall fescue resulted in rapidly decreased circulating copper $(\mathrm{Cu})$ and ceruloplasmin oxidase activity in cattle (Stoszek et al. 1979); however, body weight gains were not improved by $\mathrm{Cu}$ supplementation. Recent work indicates serum $\mathrm{Cu}$ concentrations were decreased in E+ compared to E- tall fescue (Dennis et al. 1998, Oliver et al. 2000). In a related report, steers grazing E+ compared to Etall fescue had reduced ceruloplasmin and serum $\mathrm{Cu}$ (Saker et al. 1998). The steers grazing E+ tall fescue also had lowered indices of immunological competency (lowered phagocytic activity and MHC class II expression). Copper supplementation increased the MHC class II expression regardless of forage endophyte status. Additionally, $\mathrm{Cu}$ is required for hair pigmentation and red blood cell production (Barragry 1994). Perhaps the decreased circulating $\mathrm{Cu}$ levels contributes to the bronzed hair coat observed in Angus cattle grazing E+ tall fescue.

Blood Cells. The results of a 3 year grazing study indicate that the effect of E+ tall fescue was an increase in numbers of circulating red blood cells, however, there was a reduction in both mean red blood cell volume and hemoglobin concentration in each cell (Oliver et al. 2000). These changes in red blood cell volume and hemoglobin are congruous with a decrease in circulating $\mathrm{Cu}$. Earlier work (Steen et al. 1979, Bond et al. 1984) indicated the hematocrit was likely suppressed in cattle grazing E+ tall fescue. In contrast, circulating numbers of red blood cells were not reduced in cattle on endophyte containing diets (Rhodes et al. 1991). Since $\mathrm{Cu}$ is related to red blood cell production, $\mathrm{a} \mathrm{Cu}$ deficiency could alter red blood cell para- meters. Oliver (1997) indicated both total circulating leukocytes and individual types of leukocytes (neutrophils, lymphocytes, eosinophils and monocytes) were lowered in calves on E+ tall fescue, suggesting lowered immunocompetence. However, in a later report (Oliver et al. 2000) only eosinophil numbers were reduced by $\mathrm{E}+$ tall fescue.

Immunological effects. Saker et al. (1998) indicated cattle on $\mathrm{E}+$ tall fescue had lowered indices of immunological function. Additionally, a decreased antibody titer in response to tetanus toxin occurred in steers grazing on E+ tall fescue (Dawe et al. 1997) and in rats on E+ diets challenged with sheep red blood cells (Dew et al. 1990). In contrast, Rice et al. (1997) reported greater antibody response in challenged cattle grazing E+ tall fescue. Further evidence of immunosuppression is indicated by the decreased serum globulin concentrations in steers grazing E+ (Schultze et al. 1999). Both the alpha and gamma globulin fraction decreased, but the largest decrease occurred in the gamma globulin fraction. Since gamma globulins are of lymphoid origin (Duncan et al. 1994), this could explain decreased immune responses. In support of these experimental observations, Purdy et al. (1989) reported that steers that had been on E+ had increased morbidity and mortality following movements to feedlots.

Pathogenesis. Necropsy changes observed in cattle that had grazed E+ tall fescue were mostly limited to a thickening of the smooth muscle layer of the arterioles (Oliver and Schultze 1997). There were GI tract lesions in several animals indicating abscesses, enteritis and colitis. Similarly, in earlier findings in cattle that had grazed E+ tall fescue, Garner and Cornell (1985) reported swollen arterioles upon necropsy. Therefore, changes in cattle on E+ tall fescue are largely referable to the cardiovascular system. The pathogenesis associated with ergotism is also described as due to stimulation of smooth muscles in blood vessels (primarily arterioles) with congestion proximal to the resulting vasoconstriction and ischemia distal to the vessel spasm (Osweiler 1981).

Ergot alkaloids mediated cytotoxicity upon the endothelial portion of blood vessels in cattle grazing E+ tall fescue (Oliver 1997). The vascular endothelium is a known target for the ergot alkaloids (Thompson et al. 1950). The endothelial cells are metabolically active and serve as an interface for toxic agents (Gimbrone 1986). Biologically active agents of endothelial origin, endothelin, von
Willibrand factor, and angiotensin converting enzyme, were elevated in sera of cattle grazing E+ tall fescue (Oliver 1997). Endothelin is a potent vasoconstrictor agent and is mitogenic (Anggard et al. 1990). Angiotensin converting enzyme results in the production of angiotensin II, a potent vasoconstrictor enzyme (Hoorn and Roth 1993). Von Willibrand factor is an adhesion molecule for platelets during vascular injury (Blann 1993). Additionally, thromboxane $\mathrm{B}_{2 \mathrm{a}}$ (stable metabolite of thromboxane $\mathrm{A}_{2}$ ) a potent vasoconstrictor from platelets, was reportedly elevated in the sera of cattle on E+ tall fescue (Oliver 1997). This agent also has bronchoconstrictive effects in the lung (Campbell 1990). Recently, it was found that steers grazing E+ compared to E- tall fescue had a greater response to lipopolysaccharide as measured by increases in tumor necrosis factor, a catabolic agent (Filipov et al. 1999); indicating that E+ tall fescue sensitizes the animal to other excitatory agents.

In summary, the pathogenesis of fescue toxicosis appears to originate from damage to the vascular endothelium. Endothelial cells release mediators that result in smooth muscle cell proliferation in the arterioles. Further exposure of blood vessels results in vaso-constriction with ischemia so that nutrient flux is altered and dissipation of heat is reduced. The decrease in blood perfusion to the skin and lungs would contribute to heat stress while the same effect upon the GI tract would result in altered nutrient flux. The more distal portions of the body would be most compromised by this scenario with the resultant loss of tail tips and limb digits. The effects upon reproduction could be either as a direct effect of ergot alkaloids upon embryos, decreased nutient delivery to the uterus, or altered uterine environment. A direct effect of ergot alkaloids upon the brain may lead to increased body temperature and decreased intake.

\section{Ergotism}

Ergot toxicity or ergotism occurs as the result of ingestion of the scelerotia of Claviceps purpurea found on feed grains and pasture grasses. Ergot alkaloids identified with the toxicosis have been identified (Porter et al. 1987). The major ergot alkaloids found in sclerotia on fescue, wheat, and barley were ergotamine, ergocristine and ergosine. Additionally, ergocornine and ergocryptine were associated ergotized annual ryegrass (Schneider 


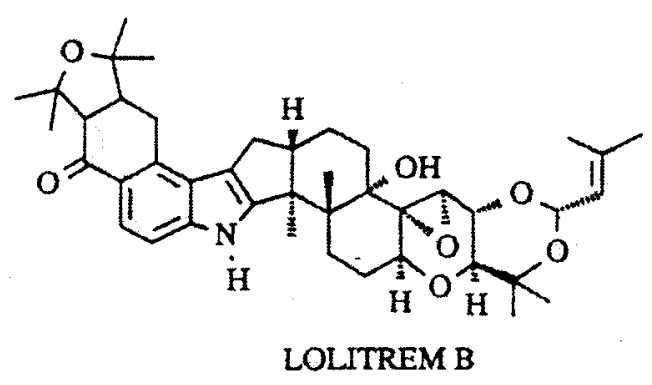

Fig. 3. Alkaloids found in endophyte-infected perennial ryegrass (ergot alkaloids not shown)(Porter 1994).

et al. 1996). The scelerotia of the fungus replaces some of the seedhead and appear as elongated dark-brown bodies of variable size.

The signs of ergotism resemble fescue toxicosis (Robbins et al. 1986, Schneider et al. 1996). This similarity in signs is natural as both are the result of ergot alkaloid toxicity. Hyperthermia, decreased intake, peripheral vasoconstriction leading to lameness and gangrene of distal portions of the body especially in the hind limb characterize both conditions in cattle (Coppock et al. 1989, Mantle 1978a, Robbins et al. 1986). Barley ergot fed to heifers resulted in tail sloughing, retained winter coats, increased salivation, and respiratory rates during hot weather (Skarland and Thomas 1972). Cold weather predisposed cattle fed ergot to lameness and gangrene (Mantle 1978b). Pregnant heifers fed ergot failed to abort (Mantle 1978b), however, some ewes aborted following ergot feeding (Greatorex and Mantle 1974). Sheep fed either ergot or ergotamine had anorexia, hyperventilation, excessive salivation, cold extremities, and some had necrosis of the tongue (Greatorex and Mantle 1973). Ergotism has resulted in severe loss of milk production associated with loss of body mass and infertility occurred in dairy cows (Schneider et al. 1996). A reduction in serum prolactin was associated with the toxicity.

Gross and microscopic changes associated with ergot resemble the vascular changes in fescue toxicosis. In cattle, constriction of arterioles, endothelial damage, vascular stasis, thrombosis, ischemia, and gangrene are described (Burfening 1973). Another cattle report included areas of skin necrosis at the base of the ear, flanks, tailhead, and around the distal portions of the limbs (Coppock et al. 1989). Microscopically arterioles were thickened. Grossly there was distal swelling of the limbs with a demarcating line between viable and non-viable tissue. In another report, gangreneous lesions on the rear of the fetlock characterized ergotism in cattle (Woods et al. 1966). Intestinal inflammation has been observed in both cattle and sheep with ergotism (Coppock et al. 1989, Greatorex and Mantle 1973). The pathogenesis of ergotism and fescue toxicosis is identical with the disturbances resulting from endothelial damage to the vascular system. Reference is made to the pathogenesis of fescue toxicosis for this discussion.

\section{Perennial Ryegrass}

Perennial ryegrass (Lolium perenne L.) is of minor significance as an eastern temperate forage grass (Balasko et al. 1995). It's primary region of adaptation is the wet and cool climate of the northeastern United States and seed production regions of the Willamette Valley in Oregon. As with tall fescue, perennial ryegrass is infected with a mutualistic endophyte, Neotyphodium lolii, and E+ ryegrass has increased growth and density compared to the non-infected forms (Cunningham et al. 1993). Insect resistance mediated by the endophyte can have a significant impact on the agronomic qualities of a pasture, as Argentine stem weevil (Listronotus bonanensis) kills the growing points of the Egrass plant (Prestidge and Gallagher 1988). The alkaloids found in $N$. coenophialum infected tall fescue are also found in $N$. lolii infected perennial ryegrass, but in addition, $N$. lolii produces tremorgenic indolediterpene alkaloids (lolitrems) (Fig. 3). These tremorgenic alkaloids produce involuntary convulsing when animals are stressed by excitation (Fletcher 1982). Hence, livestock producers utilizing perennial ryegrass are faced with the same dilemma as those utilizing tall fescue in that they can use a toxic forage base (endophyte-infected) or a nonsustainable endophyte free variety.
Animal Toxicosis-Perennial Ryegrass. The effect of grazing endophyte-infected $(\mathrm{E}+)$, lolitrem B-free E+ and E- varieties of perennial ryegrass upon animal performance and the incidence of ryegrass staggers has been reported (Fletcher 1993, Cunningham et al. 1993).

Animal Performance. Live weight gains were reduced in sheep grazing E+ perennial ryegrass in the absence of ryegrass staggers (Fletcher and Barrell 1984); indicating a direct effect of the endophyte. Depressed body weight gains occurred only in association with summer conditions and the endophyte. Reduced serum prolactin also was associated with the endophyte, presumably as the result of ergovaline (Davies et al. 1993b). Grazing the lolitrem B-free varieties of E+ perennial ryegrass over an extended period did not result in improved live weight gains over other perennial ryegrass endophyte associations, however, animals grazing the endophyte-free variety had the greatest gain (Fletcher and Sutherland 1993a). Therefore, other anti-quality factor(s) associated with the endophyte depressed gains in the absence of lolitrem B.

Staggers. Ryegrass staggers is a neuromuscular disease that is of major animal health significance in sheep, cattle and horses in New Zealand and Australia. It is most prevalent in warm drought conditions and is associated with close grazing (less than $2.5 \mathrm{~cm}$ ) and when animals are disturbed (Keogh 1973). Ryegrass staggers occurs sporadically in most years on $\mathrm{E}+$ perennial ryegrass in Australia (Cunningham et al. 1993). Severe outbreaks have resulted in substantial livestock losses with the greatest loss in young lambs suggesting altered lactation (Foot et al. 1988).

Animals with ryegrass staggers may appear normal or have a fine tremor of the head and neck at rest. When affected animals are excited they move with a stiff, uncoordinated, jerky gait that affects either the front limbs or all limbs. Severely affected animals may collapse with tetanic seizures, but rise and move normally within a few minutes once the source of excitement is removed (Mortimer and di Menna 1985). Generally there are few deaths in affected livestock unless associated with misadventure and animals generally recover when moved to E- pastures (Cunningham et al. 1993). Lesions associated with this condition are primarily biochemical, however, muscle fiber degeneration and degeneration of Purkinje's cells in the cerebellum have been microscopically described (Munday 
et al. 1985). These changes are considered the result of altered neuronal metabolism, neuronal exhaustion, and anoxic conditions during seizures. The tremorgenic action of several mycotoxins including paxilline have been attributed to binding to the gamma amino butyric acid (GABA) receptors in neural tissue and inhibiting GABA stimulation of $\mathrm{Cl}^{-}$uptake (Gant et al. 1987). The significance of this inhibitory effect is found in the fact that GABA is the major inhibitory neurotransmitter in the nervous system. Consequently, receptor blockade of the GABA system results in increased sensitivity to stimulii.

Heat Stress. Increased respiratory rates and rectal temperatures have been associated with grazing $\mathrm{E}+$ perennial ryegrass (Fletcher 1993). The rectal temperature increase in a stressed environment was greatest in the animals grazing E+ ryegrass compared to E-, however, rectal temperatures were intermediate in lambs on E+ lolitrem B-free ryegrass. This increase in rectal temperature was attributed to ergovaline in the E+ lolitrem-free forage. Animals with the greatest increase in respiratory rates grazed forage with the largest concentration of ergovaline. It is presumed that the presence of ergovaline results in the effects as described for fescue toxicosis.

Fecal Contamination and Fly Strike. Fecal contamination of wool and flystrike involving flies laying eggs in the skin beneath fecal contaminated areas is a major economic problem in New Zealand associated with grazing E+ perennial ryegrass (Fletcher and Sutherland 1993b). Lambs grazing E- perennial ryegrass did not have these problems whereas this occurred in $29-31 \%$ of the animals on E+ perennial ryegrass.

\section{Phalaris Species (Reed Canarygrass)}

Reed canarygrass (Phalaris arundinacea $L$.) is utilized primarily in the northern half of the United States (Sheaffer and Martin 1995). It is adapted to poorly drained or flooded areas and can be invasive in these habitats (Merigliano and Lesica 1998). Its primary utilization is in low lying areas where spring melting snows or streambanks provide moist habitats. Reed canarygrass is also drought intolerant and, therefore, has limited use in the southeastern U.S. (Sheaffer and Martin 1995). Reed canarygrass may contain methoxy-methyl tryptamine, 2 methyl tryptamine, 2 methoxy-tetrahydro-b-car-
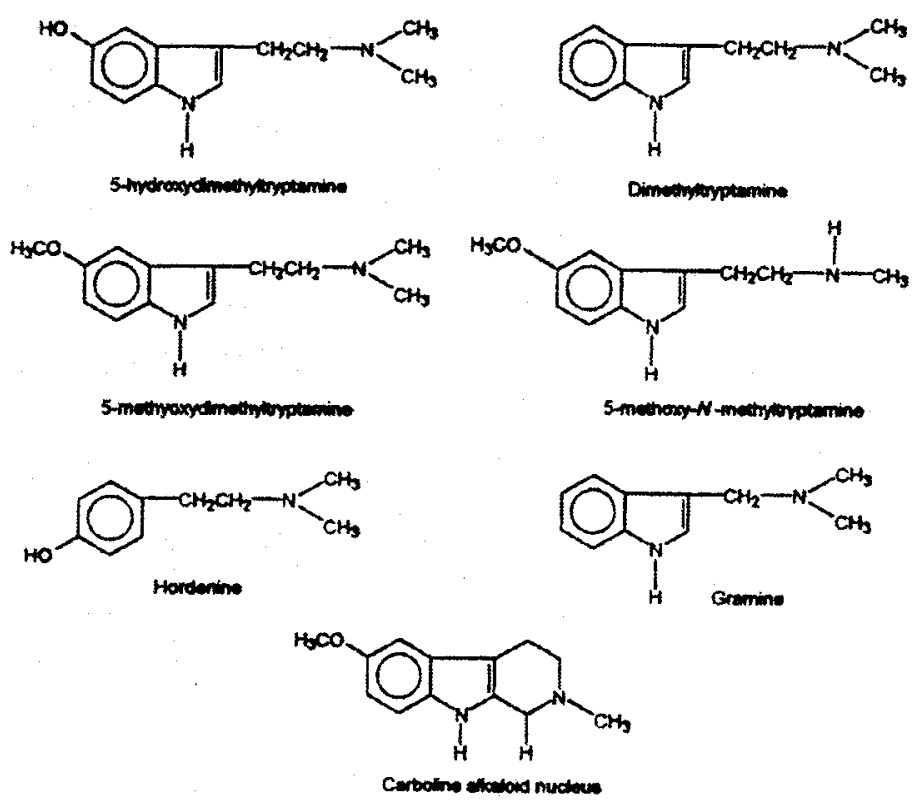

Fig. 4. Alkaloids found in reed canary grass (Phalaris sp.) that are similar to serotonin (Cheeke 1998).

boline, hordenine, and gramine alkaloids (Marten 1973). Structures of these alkaloids are in Fig. 4 (Cheeke 1998). These alkaloids are concentrated in the immature leaf sheaths and blades (Woods et al. 1979). They reduce palatability of the grass, and thus serve as animal deterrants to prevent overgrazing (Marten et al. 1976). The tryptamine and carboline alkaloids create digestive disorders resulting in a greater incidence of diarrhea in sheep compared to either the hordenine or gramine alkaloids (Marten et al. 1981). Hordenine and gramine alkaloids simply reduce average daily gains. Hence, there are metabolic differences in modes of action; however, forage refusal correlates better with total alkaloid concentration than with the individual alkaloid classes (Marten et al. 1976). The alkaloids in reed canarygrass are under simple genetic control and are highly heritable (Marum et al. 1979, Woods et al. 1979). Fortunately, low alkaloid cultivars are commercially available. Therefore, the obvious solution for prevention of Phalaris staggers is to replant with low-alkaloid cultivars.

Field outbreaks of Phalaris toxicity have been reported for sheep and cattle (Bourke et al. 1990, Nicholson et al. 1989). In sheep 2 toxicological entities occur: a "sudden death" syndrome and a nervous syndrome (Bourke et al. 1988). The "sudden death" is characterized by sudden collapse especially when excited and is associated with cardiac abnormalities, cyanotic mucous membranes and disturbed respiration. Affected sheep either die immediately or recover spontaneously
(Gallagher and Koch 1964). The problem occurred when $P$. aquatica $\mathrm{L}$. dominated the pasture with rapidly growing plants (Blood and Radostits 1989). Signs have occurred within 4 hours of going on pasture but usually between 12 and 72 hours after exposure. The cardiac disorder associated with "sudden death" has been attributed to an unknown toxin other than the tryptamine alkaloids (Bourke et al. 1988). The cardiac syndrome or "sudden death" was regarded to be the result of forced exercise in sheep already exhibiting nervous signs. Anderton et al. (1994) suggested N-methyltyramine (structurally related to hordenine) is causative. Both tryptamine and tyramine alkaloids being monoamine oxidase inhibitors provides a mechanism for a cardiotoxic effect.

The typical nervous form occurs after more protracted exposure, usually 2-3 weeks after sheep are put on new growth pasture (Blood and Radostits 1989). The following signs were described: thoracic limb paresis, pelvic limb paresis, disturbed equilibrium, hypermetria of the thoracic limbs, fine mild tremors and a bounding pelvic gait (Bourke et al. 1990). Affected sheep often are conscious and frightened when approached. If they are recumbent, they struggle in an attempt to rise. New cases have occurred in association with forced exercise for as long as 12 weeks after removing sheep from the pasture (Blood and Radostits 1989). The nervous signs were replicated following administration of the Phalaris alkaloids, 5methoxy dimethyltryptamine, gramine and hordenine, with the former being the most 
potent (Bourke et al. 1990). Phalaris alkaloids act by binding to neural serotinergic receptors that inhibit neurotransmission in those pathways. Provision of cobalt to iodinized salt is preventive (Duynisveld and Wittenberg 1993).

Signs of toxicosis in cattle include stiffness of the hocks, dragging the hind feet, incoordination of the tongue and lips which results in eating difficulty. Consequently, affected bulls died after a wasting disease associated with $P$. caroliniana (Nicholson et al. 1989). Microscopically degenerative lesions of spinal cord tracts and in the cerebellum of sheep have been observed (Blood and Radostits 1989). Also, an abnormal greenish pigment has been seen in the renal medulla and in parts of the brain.

Animal Production. Total indole alkaloid concentration (gramine, tryptamines and carbolines) was inversely correlated with weight gains in lambs and steers (Marten et al. 1976). Marten et al. (1981) indicated that a total alkaloid concentration greater than $2.0 \mathrm{mg} / \mathrm{g}$ dry weight of forage reduces animal gains. Similarly, palatability was correlated with total alkaloid concentration (Simons and Marten 1971). Recently released cultivars of reed canarygrass, 'Rival' and 'Venture', contain only gramine and hordenine (Duynisveld and Wittenberg 1993). Lamb gains were superior on these cultivars early in the grazing season compared to 'Frontier' reed canarygrass, a cultivar containing the methoxy derivatives of the tryptamines and B-carbolines; however, overall ADG was similar for the 3 cultivars. Gramine concentration exceeded 2.0 $\mathrm{mg} / \mathrm{g}$ during a portion of the trial in all 3 cultivars and this was assumed to be the factor that reduced gains in Rival and Venture in the latter half of the grazing season.

\section{Ryegrass Toxicosis}

Annual ryegrass (Lolium multiflorum Lam., Lolium rigidum Gaud. in Australia) is grown on approximately 1 million hectares in the United States, of which over $90 \%$ is found in the southeast (Balasko et al. 1995). Annual ryegrass is infected with an endophytic fungus whose dissemination is fastidious compared to endophytes belonging to the genus Neotyphodium. The endophyte resides in the basal $2 \mathrm{~mm}$ of the tiller, and is troublesome to locate in developing seedheads, but it is passed from one generation to the next in a limited number of seed within the raceme (Latch et al. 1987, Nelson and Ward 1990). The endophyte has no adverse effects on livestock (Hickey and Hume 1994) nor does it provide resistance to insect predation (Prestidge 1991). While the endophye is termed "Acremonium-like" there is no taxonomic evidence suggesting a common ancestry with Neotyphodium.

Animal Toxicosis. Annual ryegrass (Lolium rigidum) toxicosis in livestock is a neurological disease caused by grazing annual ryegrass parasitized by the nematode, Anguina agrostis (McIntosh et al. 1967). The causative agents are corynetoxins (Fig. 5) produced by the bacterium, Clavibacter toxicus, which is carried into the seedhead by the nematode (Riley and Ophel 1992). The infected flower does not produce seed, but is replaced by a gall. There appears to be a requirement for the

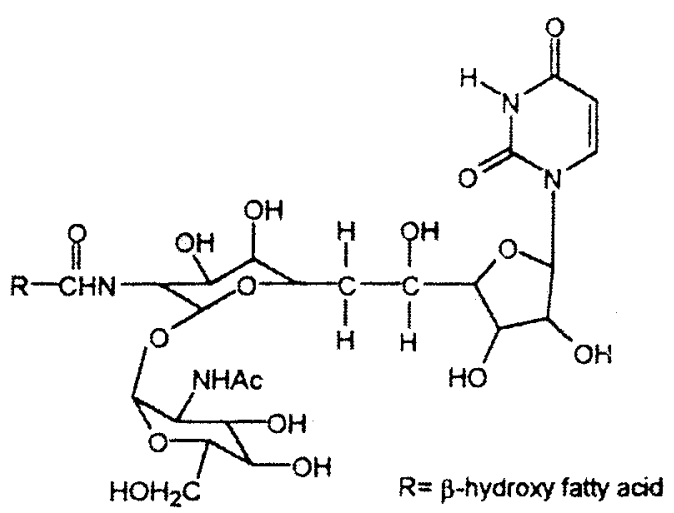

Fig. 5. Corynetoxin alkaloids found in toxic galls on annual ryegrass (Cheeke 1998).

bacteria to be infected with a bacteriophage before the toxin can be produced (Ophel et al. 1993). The bacterium produces a yellow slime on the seed heads. Toxic nematode galls are orange in color whereas, the non-toxic gall is dark brown or black. Nematodes in the gall may be visualized microscopically following addition of water to the dry gall (McKay and Riley 1993).

The mechanism of action of the corynetoxins involves inhibition of an enzyme, uridine diphospho-N-acetylglucosamine:dolichol-phosphate N-acetyl-glucosamine phosphate transferase (UDT) necessary for glycosylation of proteins (Jago et al. 1983). Therefore, toxicity results from depletion or reduced activity of essential glycoproteins found in enzymes, hormones, components of the cell membrane and membrane receptors (Jago et al. 1983).

Toxicosis may appear as soon as 2 days or as late as 12 weeks after grazing the toxic forage. Signs in sheep associated with this toxicosis include a high stepping gait, lack of coordination and convulsions (Cheeke 1998). An animal may have a convulsion and recover or remain recumbent and die with their feet in a paddling motion. Signs appear most obvious when the animals are excited and resemble ryegrass staggers, however, a substantial mortality is associated with annual ryegrass toxicosis. Convulsions and lack of coordination has been described for cattle and horses that had access to galls found on chewing red fescue (Festuca rubra commutata Gaud.) (Galloway 1961). Annual ryegrass toxicosis per se has also been reported in horses (Creeper et al. 1996).

The lethal dose of corynetoxins given orally to sheep was $5 \mathrm{mg} / \mathrm{kg}$. This total lethal dose was the same whether administered as a single dose or as repeated smaller doses with a maximum interval of 9 weeks between doses being examined (Jago and Culvenor 1987). Therefore, the toxic effect is cumulative. Corynetoxins result in extensive damage to the cerebellum via damage to the endothelial cells in capillaries (Finnie and Mukherjee 1987). Gross and microscopic pathology includes lipid deposition in the liver, diffuse hemorrhages, and perivascular edema particularly in the cerebellar meninges (Blood and Radostits 1989).

Hepatic damage determined by increases in the serum concentration of 2 hepatic enzymes, aspartate amino transferase (AST) and glutamate dehydrogenase (GLDH) occurred in ewes given sublethal doses of corynetoxins (Davies et al. 1996). 
There was no effect of this treatment on body weight and reproduction was not adversely affected. However, wool growth and wool fiber diameter were reduced. Anorexia and rumen stasis has been reported in acutely affected sheep (Berry et al. 1976).

Some protective effect from corynetoxins was found by dosing sheep with cobalt sulfate $\left(4.0 \mathrm{Mg} / \mathrm{Day}^{-1}\right.$ ) (Davies et al. 1993a). Cobalt treatment prevented the rise in the serum concentration of AST and GLDH but did not prevent the suppression of UDT in the liver. It was thought that cobalt treatment would enhance the growth of microorganisms in the rumen that would metabolize corynetoxins, although there was no evidence presented to indicate cobalt had this effect. Normally corynetoxins are not readily metabolized in the rumen (Vogel and McGrath 1986).

\section{Management Options to Overcome or Reduce Fescue Toxicosis}

A. Pasture and/or animal management

1. Dilution with other forages including Bermudagrass or clovers. The major problem associated with dilution with clovers is that the potential for utilizing clover varies greatly among regions. Clovers are sensitive to viruses and other diseases, plus, they are comparatively shallow rooted and are consequently subject to drought stress which often occurs during summer months.

2. Although research is limited, it appears that increased stocking rates on E+ tall fescue may improve animal performance and production.

3. Friendly endophytes. Endophyte infected cultivars, i.e., those containing nontoxic endophytes will be commercially available. Limited research suggests they will improve animal productivity; however, knowledge regarding stand persistance is unknown.

4. Withdrawal of pregnant mares from E+ tall fescue at least 30 to 60 days prior to expected foaling date should reduce problems assocated with foaling.

B. Feed treatment and/or dietary additives

1. Ammoniation of hay. Ammoniation of hay has resulted in consistent improvement in animal performance.

2. Energy supplementation. Supplementation with concentrated feedstuffs may overcome much of the negative effects.

3. Mineral supplementation. Supplementa- tion with selenum or copper have not given consistent results. Research with other mineral supplements is either limited or non-existent.

4. Ensiling. Limited research suggests it does not overcome the toxicosis.

5. Others. The use of thiamine supplementation, zeranol, aluminosiliates and activated charcoal have either given negative results, inconsistent results or have not been researched.

C. Pharmacologic compounds

1. Ivermectin. The anthelmintic appears to have some positive effect, although its mechanism of action and method of administration has not been fully researched.

2. Domperidone. It appears domperidone is an effective treatment for equine fescue toxicosis.

D. Immunologic protection

1. Although experimentation with vaccines has resulted in positive effects, none are commercially available.

\section{Management Options to Overcome Ergotism}

1. Graze intensely enough to prevent seed head development.

2. Avoid grazing or consuming ergotized seed heads.

\section{Management Options to Overcome} Perennial Ryegrass Toxicosis

1. Plant endophyte-infected lolitrem B free varieties

\section{Management Options to Phalaris sp. Toxicosis}

1. The long-term solution is to plant low alkaloid cultivars.

2. The most common option utilized is to avoid planting reed canarygrass and utilizing another cool-season perennial.

\section{Management Options to Annual Ryegrass Toxicosis}

1. First of all, it doesn't appear to be a major problem in the U.S.

2. In outbreak situations, dosing, sheep with cobalt sulfate appears to have some benefit.

\section{Literature Cited}

Aiken, G.E., D.I. Bransby, and C.A. McCall. 1993. Growth of yearling horses compared to steers on high- and low-endophyte infected tall fescue. J. Equine Vet. Sci. 13:26-28.
Aldrich, C.G., J.A. Paterson, J.L. Tate, and MS. Kerley. 1993a. The effects of endophyte-infected tall fescue consumption on diet utilization and thermal regulation in cattle. J. Anim. Sci. 71:164-170.

Aldrich, C.G., M.T. Rhodes, J.A. Paterson, and MS. Kerley. 1989. The effects of tall fescue endophyte-fungus and the dopamine antagonist metoclopramide on voluntary diet consumption, digestibility and body temperature in lambs. J. Anim. Sci. 67(Suppl.1):695.

Aldrich, C.G., M.T. Rhodes, J.L. Miner, MS. Kerley, and JA. Paterson. 1993b. The effects of endophyte-infected tall fescue consumption and use of a dopamine antagonist on intake, digestibility, body temperature, and blood constituents in sheep. J. Anim. Sci. 71:158-163.

Anderton, N., PA. Cockrum, and J.A. Edgar. 1994. Identification of a toxin suspected of causing sudden death in livestock grazing Phabaris pastures. p. 269-274. P.R. Dorling and S.M. Colegate (eds.), Plant-associated toxins. Agricultural, phytochemical and ecological aspects. CAB International, Wallingford, UK.

Anggard, E.E., R.M. Botting, and J.R. Vane. 1990. Endothelium-derived vasoconstricting factors. p. 7-20. In: J.B. Warren (ed.), The endothelium, an introduction to current research. Wiley Liss, New York.

Balasko, JA., G.W. Evers, and R.W. Duell. 1995. Bluegrasses, ryegrasses and bentgrasses. p. 357-370. In: R.F. Barnes, D.A. Miller, and C.J. Nelson (eds.), Forages. Volume I: An introduction to grassland agriculture. Iowa State Univ. Press, Ames, Ia.

Ball, D.M., C.S. Hoveland, and GD. Lacefield. 1996. Southern Forages. p. 169-174. Potash and Phosphate Institute. Atlanta, Ga.

Barragry, T. 1984. Anthelmintics: A review. N.Z. Vet. J. 32:161-164.

Barragry, T.B. 1994. Veterinary drug therapy. p. 737-743. In: Lea \& Febiger, Philadelphia, Penn.

Beede, D.K. and R.J. Collier. 1986. Potential nutritional strategies for intensively managed cattle during thermal stress. J. Anim. Sci. 62:543-554.

Berry, P.H., R.D. Cook, J. McHoweH, R.R. White, and D.A. Purcell. 1976. Lesions in sheep and guinea pigs pen fed parasitised annual ryegrass (Lobium rigidum). Aust. Vet. J. 52:540-541.

Blann, A.D. 1993. Is raised von Willebrand factor a marker of endothelial cell damage? Med. Hypotheses 41:419-424.

Blood, D.C. and OM. Radostits. 1989. Veterinary medicine: A textbook of the diseases of cattle, sheep, pigs, goats and horses. p. $1328-1329.7^{\text {th }}$ edition. Bailliere Tindall, Philadelphia, Penn.

Boling, J.A. 1985. Endophytic fungus and tall fescue utilization by ruminants. Prof. Anim. Sci. 1:19.

Boling, J.A., L.D. Bunting, G.M. Davenport, J.L. Van der Veen, K.M. Meekins, NW. Bradley, and R.E. Kohls. 1989. Physiological responses of cattle consuming 
tall fescue to environmental temperature and supplemental phenothiazine. J. Anim. Sci 67:2377-2385.

Bolt, D.J. and J. Bond. 1989. Effects in pregnant beef heifers grazing fungus-infected tall fescue on birth weight, milk yield and calf growth. Nutr. Rep. mt. 40:487-494.

Bolt, D.J., J. Bond, and T. Elsasser. 1983. Changes in plasma prolactin and grazing behavior in heifers treated with dopamine antagonist while grazing tall fescue and orchardgrass pasture. J. Anim. Sci. 57(Suppl 1):48.

Bond, J., G.P. Lynch, D.J. Bolt, H.W. Hawk, C. Jackson, and R.J. Wall. 1988. Reproductive performance and lamb weight gains for ewes grazing fungus-infected tall fescue. Nutr. Rep. Int. 37:1049-1115.

Bond, J., J.B. Powell, D.J. Undersander, P.W. Moe, H.F. Tyrell, and R.R. Oltjen. 1984. Forage composition, growth and physiological characteristics of cattle grazing varieties of tall fescue during summer conditions. J. Anim. Sci. 59:584-593.

Bourke, C.A., M.J. Carrigan, and R.J. Dixon. 1988. Experimental evidence that tryptamine alkaloids do not cause Phabaris aquatica sudden death syndrome in sheep. Aust. Vet. J. 65:218-220.

Bourke, C.A., M.J. Carrigan, and R.J. Dixon. 1990. The pathogenesis of the nervous syndrome of Phabaris aquatica toxicity in sheep. Aust. Vet. J. 67: 356-358.

Bransby, D.I. 1997. Steer weight gain responses to ivermectin when grazing fescue. Large Animal Practice May/June 16-19.

Brendemuehl, J.P., T.R. Boosinger, D.G. Pugh, and R.A. Shelby. 1994a. Influence of endophyte-infected tall fescue on cyclicity, pregnancy rate and early embryonic loss in the mare. Theriogenology 42:489-500.

Brendemuehl, J.P., T.R. Boosinger, D.I. Bransby, D.D. Kee, J. Schumacher, RA. Shelby, and M.R. Putnam. 1994b. The effects of short term exposure to and removal from the fescue endophyte Acremonium coenophiabum on pregnant mares. p. 11-12. In: Society for the Study of Reproduction, Inc., Madison, Wis., Proc. Sixth Int'l. Sym. Equine Reprod.

Browning, R., Jr., F.N. Thompson, J.L. Sartin, and M.L. Leite-Browning. 1997. Plasma concentrations of prolactin, growth hormone, and luteinizing hormone in steers administered ergotamine or ergonovine. $\mathbf{J}$ Anim. Sci. 75:796-802.

Burfening, P.J. 1973. Ergotism. J. Amer. Vet. Med. Assoc. 163(11):1288-1290.

Bush, L.P., J. Boling, and S. Yates. 1979. Anim. Disorders. Tall Fescue 247-292.

Campbell, W.B. 1990. Lipid-derived antacoids: eicosanoids and platelet-activating factor. p. 600-618. In: A.G. Goodman, T.W Rall, A.S. Nies, and P. Taylor (eds.), Goodman and Gilman's The pharmacological basis of therapeutics. $8^{\text {th }}$ edition. Pergamon Press, New York.

Cheeke, P.R. 1998. Natural toxicants in feeds, forages, and poisonous plants. 2nd edition. Interstate Publishers, Inc., Danville, Ill.
Chestnut, A.B., H.B. Fribourg, J.B. McLaren, D.G. Keltner, B.B. Reddick, R.J. Carlisle, and MC. Smith. 1991. Effects of Acremonium coenophiabum infestation, bermudagrass, and nitrogen or clover on steers grazing tall fescue pastures. J. Prod. Agr. 4:208-219.

Clay, K. 1989. Clavicipitaceous endophytes of grasses: their potential as biocontrol agents. Mycol. Res. 92:1-12.

Clay, K., T.N. Hardy, and A.M. Hammond, Jr. 1985. Fungal endophytes of grasses and their effects on an insect herbivore. Oecologia 66:1-6.

Coppock, R.W., MS. Mostrom, J.Simon, D.J. McKenna, B. Jacobsen, and H.L. Szlachta. 1989. Cutaneous ergotism in a herd of dairy calves. J. Amer. Vet. Med. Assoc. 194:549-551.

Cornell, C.N., J.V. Lueker, G.B. Garner, and J.L. Ellis. 1990. Establishing ergovaline levels for fescue toxicosis, with and without endoparasites, under controlled climatic conditions. p. 75-79. In: S.S. Quisenberry, and R. E. Joost (eds.), Proc. Int'l. Symp. on Acremonium/grass interactions. Louisiana Agr. Exp. Station, Baton Rouge, La.

Creeper, J.H., W. Vale, and R. Walsh. 1996. Annual ryegrass toxicosis in horses. Aust. Vet. J. 74:465-466.

Cross, D.L. 1997. Fescue toxicosis in horses. p. 289-309. In: C.W. Bacon and N.S. Hill (eds.), Neotyphodium/grass interactions. Plenum Press, New York.

Cunningham, P.J., J.Z. Foot, and K.F.M. Reed. 1993. Perennial ryegrass (Lolium perenne) endophyte (Acremonium lolii) relationships: the Australian experience. Agr. Ecosys. Environ. 44:157-169.

Danilson, D.A., S.P. Schmidt, C.C. King, L.A. Smith, and W.B. Webster. 1986. Fescue toxicity and reproduction in beef heifers. J. Anim. Sci. 63(Suppl. 1):296.

Davies, S.C., C.L. White, I.H. Williams, J.G. Allen, and K.P. Croker. 1996. Sublethal exposure to corynetoxins affects production of grazing sheep. Aust. J. Exp. Agr. 36:649-655

Davies, S.C., I.H. Williams, C.L. White, J.G. Allen, J.G. Edgar, P.A. Cockrum, and P. Stewart. 1993a. Protective effect of cobalt against apparent liver damage in sheep exposed to toxic annual ryegrass. Aust. Vet. J. 70:186-187.

Davies, E., G.A. Lane, G.C.M. Latch, B.A. Tapper, I. Garthwaite, N.R. Towers, L.R. Fletcher, and D.B. Pownall. 1993b. Alkaloid concentrations in field-grown synthetic perennial ryegrass endophyte association. p. 72-76. In: D.E. Hume, G.C.M. Latch, and H.S. Easton (eds.), Biology and ecology of acremonium endophytes, Proc. $2^{\text {nd }}$ Internat. Symp. on Acremonium/grass interactions. Palmerston North, New Zealand.

Dawe, D.L., J.A. Stuedemann, N.S. Hill, and F.N. Thompson. 1997. Immune suppression in cattle grazing endophyte-infected tall fescue. p. 411-413. In: C.W. Bacon and N.S. Hill (eds.), Neothyphodium/Grass Interactions. Plenum Press, New York.
Dennis, S.B., V.G. Allen, KE. Saker, J.P. Fontenot, J.Y.M. Ayad, and C.P. Brown. 1998. Influence of Neotyphodium coenophiabum on copper concentration in tall fescue. J. Anim. Sci. 76:2687-2693.

Dew, R.K., G.A. Boissonneault, N. Gay, J.A. Boling, R.J. Cross, and D.A. Cohen. 1990. The effect of the endophyte (Acremonium coenophiabum) and associated toxin(s) of tall fescue on serum titer response to immunization and spleen cell flow cytometry analysis and response to mitogens. Vet. Immunol. Imunopathol. 26:285-295.

Dougherty, C.T., L.M. Lauriault, N.W. Bradley, N. Gay and P.L. Cornelius. 1991. Induction of tall fescue toxicosis in heat-stressed cattle and its alleviation with thiamin. J. Anim. Sci. 1008-1018.

Duncan, J.R., K.W. Prasse, and E.A. Mahaffey. 1994. Veterinary laboratory medicine: Clinical pathology. pp 112-118, 132-136. 3rd ed. Iowa State Univ. Press, Ames, Ia.

Duynisveld, G.W. and Wittenberg, K.M. 1993. Evaluation of rival, venture and frontier reed canarygrass as pasture forage. Can. J. Anim. Sci. 73:89-100.

Dyer, D.C. 1993. Evidence that ergovaline acts on serotonin receptors. Life Sci. 53:223-228.

Earle, W.F., D.L. Cross, LW. Hudson, L.M. Redmond, and S.W. Kennedy.1990. Effect of energy supplementation on gravid mares grazing endophyte-infected J. Equine Vet. Sci. 10:126-130.

Eisemann, J.H., D.E. Bauman, D.E. Hogue, and H.F. Travis. 1984. Influence of photoperiod and prolactin on body composition and in vitro lipid metabolism in wether lambs. J. Anim. Sci. 59:95-104.

Elsasser, T.H. and D.J. Bolt. 1987. Dopaminergic-like activity in toxic fescue alters prolactin but not growth hormone or thyroid stimulating hormone in ewes. Domestic Anim. Endocrinology 4:259-269.

Elsasser, T.H., T.S. Rumsey, and A.C. Hammond. 1989. Influence of diet on basal and growth hormone-stimulated plasma concentrations of IGF-1 in beef cattle. J. Anim. Sci. 67:128-141.

Filipov, N.M., F.N. Thompson, J.A. Stuedemann, T.H. Elsasser, S. Kahl, R.P. Sharma, CR. Young, L.H. Stanker, and C.K. Smith. 1999. Increased responsiveness to intravenous lipopolysaccharide challenge in steers grazing endophyte-infected tall fescue compared with steers grazing endophyte-free tall fescue. J. Endocrinol. 163:213-220.

Finnie, J.W. and TM. Mukherjee. 1987. Ultrastructural changes in cerebral blood vessels of sheep injected with tunicamycin. J. Comp. Pathol. 97:217-220.

Fiorito, IM., L.D. Bunting, G.M. Davenport, and J.A. Boling. 1991. Metabolic and endocrine responses of lambs fed Acremonium coenophialum-infected or noninfected tall fescue hay at equivalent nutrient intake. J. Anim. Sci. 69:2108-2114.

Fletcher, L.R. 1982. Observations of ryegrass staggers in weaned lambs grazing different 
ryegrass pastures. New Zealand J. Exp. Agr. 10:203-207.

Fletcher, L.R. 1993. Grazing ryegrass/endophyte associations and their effect on animal health and performance. p. 115-120. In: D.E. Hume, G.C.M. Latch, and H.S. Easton (eds.), Proc. of the Second Internat. Symp. on Acremonium/grass interactions: Plenary papers. Palmerston North, New Zealand.

Fletcher, L.R. and G.K. Barrell. 1984. Reduced liveweight gains and serum prolactin levels in hoggets grazing ryegrasses containing Lobium endophyte. New Zealand Vet. J. 32:139-140.

Fletcher, L.R. and B.L. Sutherland. 1993a. Liveweight change in lambs grazing perennial ryegrasses with different endophytes. $\mathrm{p}$ 125-127. In: DE. Hume, G.C.M. Latch and H.S. Easton (eds.), Proc. Second Internat Symp. on Acremonium/grass interactions, Palmerston North, New Zealand.

Fletcher, L.R. and B.L. Sutherland. 1993b. Flystrike and faecal contamination in lambs grazing endophyte infected ryegrasses. $p$ 122-124. In: D.E. Hume, G.C.M. Latch and H.S. Easton (eds.), Proc. Second Internat. Symp. on Acremonium/grass interactions, Palmerston North, New Zealand.

Foot, J.Z., PG. Heazlewood, and L.J. Cummins. 1988. The effects of high-endophyte perennial ryegrass pastures on reproduction in memo ewes. Aust. Adv. Vet. Sci. 146-147.

Freeman, A.J., K.T. Cunningham, and M.B. Tyers. 1992. Selectivity of 5-HT3 receptor antagonists and anti-emetic mechanisms of action. Anti-Cancer Drugs 3:78-85.

Gallagher, C.H. and J.H. Koch. 1964. Toxicity of Phabaris tuberosa for sheep. Nature (London) 204:542-545.

Galloway, J.H. 1961. Grass seed nematode poisoning in livestock. J. Amer. Vet. Med. Assoc. 139:1212-1214

Gant, D.B., R.J. Cole, J.J. Valdes, M.E. Eldefrawi, and A.T. Eldefrawi. 1987. Action of tremorgenic mycotoxins on GABAA receptor. Life Sci. 41:2207-2214.

Garner, G.B. and C.B. Cornell. 1985. Cattle response to fescue. Amer. Assoc. Vet. Laboratory Diagnosticians 28:145-154.

Gay, N., J.A. Boling, R. Dew, and DE. Miksch. 1988. Effects of endophyte-infected tall fescue on beef cow-calf performance. Appl. Agr. Res. 3:182.

Gimbrone, M.A., Jr. 1986. Vascular endothelium in hemostasis and thrombosis. Churchill Livingstone, N.Y.

Glenn, A.E., C.W. Bacon, R. Price, and R.T. Hanlin. 1996. Molecular phylogeny of Acremonium and its taxonomic implications. Mycologia 88(3):369-383.

Gould, L.S. and W.D. Hohenboken. 1993. Differences between progency of beef sires in susceptibility to fescue toxicosis. J. Anim. Sci. 71:3025-3032.

Greatorex, J.C. and P.G. Mantle. 1973. Experimental ergotism in sheep. Res. Vet. Sci. 15:337-346

Greatorex, J.C. and P.G. Mantle. 1974 Effect of rye ergot on the pregnant sheep. J. Reprod. Fert. 37:33-41.
Hannah, S.M., J.A. Paterson, J.E. Williams, M.S. Kerley, and J.L. Miner. 1990. Effects of increasing dietary levels of endophyteinfected tall fescue seed on diet digestibility and ruminal kinetics in sheep. J. Anim. Sci. 68:1693-1701.

Harmon, D.L., K.L. Gross, K.K. Keikmerie, K.P. Cofffey, T.B. Avery, and J. Klindt. 1991. Effects of feeding endophyte-infected fescue hay on portal and hepatic nutrient flux in steers. J. Anim. Sci. 69:1223-1231.

Hazlett, W.D., T.L. Lester, and R.W. Rorie. 1998. Influence of endophyte-infected fescue on serum and intra-uterine insulin growth factor I and II in beef heifers. J. Anim. Sci. 76(Suppl. 1):230

Hemken, R.W., J.A. Boling, L.S. Bull, R.H. Hatton, R.C. Buckner, and L.P. Bush. 1981. Interaction of environmental temperature and anti-quality factors on the severity of summer fescue toxicosis. J. Anim. Sci. 52:710-714.

Hemken, R.W., L.S. Bull, J.A. Boling, E. Kane, L.P. Bush, and R.C. Buckner. 1979. Summer fescue toxicosis in lactating dairy cows and sheep fed experimental strains of ryegrass-tall fescue hybrids. J. Anim. Sci. 49:641-646.

Hickey, M.J. and D.E. Hume. 1994. Evaluation of 7 Italian and hybrid ryegrasses under sheep grazing in Southland, New Zealand. New Zealand J. Agr. Res. 37:495-508.

Hill, N.S. 1994. Ecological relationships of Balansiae-infected graminoids. p. 59-71. In: C.W. Bacon and J.F. White, Jr. (eds.), Biotechnology of endophytic fungi of grasses. CRC Press, Boca Raton, Fla.

Hill, N.S., D.P. Belesky, and W.C. Stringer. 1991. Competitiveness of tall fescue as influenced by Acremonium coenophialum. Crop Sci. 31:185-190.

Hill, N.S., W.C. Stringer, G.E. Rottinghaus, D.P. Belesky, W.A. Parrott, and D.D. Pope. 1990. Growth, morphological, and chemical component responses of tall fescue to Acremonium coenophialum. Crop Sci. 30:156-161

Hoom, C.M. and R.A. Roth. 1993. Monocrotaline pyrrole-induced changes in angiotension-converting enzyme activity of cultured pulmonary artery endothelial cells. Brit. J. Pharmacol. 110:597-602.

Hossner, K.L., R.H. McCusker, and M.V. Dodson. 1997. Insulin-like growth factors and their binding proteins in domestic animals. J. Anim. Sci. 64:1-15.

Hoveland, C.S. 1990. Importance and economic significance of the Acremonium endophytes to performance of animals and grass plant. p. 3-12. Proc. Internat. Symp. Acremonium/Grass Interactions. Louisiana Agr. Exp. Sta., Baton Rouge, La.

Hoveland, C.S., S.P. Schmidt, C.C. King, Jr., J.W. Odom, E.M. Clark, J.A. Mcguire, L.A. Smith, H.W. Grimes, and J.L. Holliman. 1983. Steer performance and association of Acremonium coenophialum fungal endophyte on tall fescue pasture. Agron. J. 75:821-824.
Hurley, W.L., E.M. Convey, K. Leung, L.A. Edgerton, and R.W. Hemken. 1981. Bovine prolactin, TSH, $\mathrm{T}_{4}$ and $\mathrm{T}_{3}$ concentrations as affected by tall fescue summer toxicosis and temperature. J. Anim. Sci. 51:374-379.

Jackson, JA., R.J. Harmon, and Z. Tabeidi. 1997. Effect of dietary supplementation with vitamin $\mathrm{E}$ for lactating dairy cows fed tall fescue hay infected with endophyte. J. Dairy Sci. 80:569-572.

Jago, MV. and C.C. Culvenor. 1987. Tunicamycin and corynetoxin poisoning in sheep. Aust. Vet. J. 64:232-235.

Jago, M.V., A.L. Payne, J.E. Peterson, and T.J. Bagust. 1983. Inhibition of glycosylation by corynetoxin, the causative agent of annual ryegrass toxicity: a comparison with tunicamycin. Chem-Biol. Interactions 45:223-234.

Keogh, R. 1973. Induction and prevention of ryegrass staggers in grazing sheep. NZJ Exptl. Agr. 1:55-57.

Lamberts, S.W.J. and R.M. Macleod. 1990. Regulation of prolactin secretion at the level of the lactotroph. Physiol. Rev. 70:279-318.

Larson, B. 1997. Neotyphodium toxicoses. p. 347-360. In: C.W. Bacon and N.S. Hill (eds.), Neotyphodiumlgrass interactions. Plenum Press, New York, N.Y.

Larson, B.T., JA. Paterson, MS. Kerley, and S.C. Bell. 1991. Evaluation of the rat model for studying the effects of endophyte-infected tall fescue ingestion and environmental heat exposure. J. Anim. Sci. 69(Suppl. 1):275.

Latch, G.C.M., L.R. Potter, and B.F. Tyler. 1987. Incidence of endophytes in seeds from collections of Lolium and Festuca species. Ann. Appl. Bot. 111:59-64.

Lincoln, G.A. 1990. Correlation with changes in horns and pelage, but not reproduction of seasonal cycles in the secretion of prolactin in rams of wild, feral and domesticated breeds of sheep. J. Reprod. Fertil. 90:285-296.

Lipham, L.B., F.N. Thompson, J.A. Stuedemann, and J.L. Sartin. 1989. Effects of metoclopramide on steers grazing endophyte-infected fescue. J. Anim. Sci. 67:1090-1097.

Loew, D.M., E.B. vanDeusen, and W. MeierRuge. 1978. Effects on central nervous system. p. 421. In: B. Berde and H.O. Schild (eds.), Ergot alkaloids and related compounds. Springer-Verlag, Berlin.

Mantle, P.G. 1978a. Ergotism in cattle, p. 145-151. In: T.D. Wyllie, and L.G. Morehouse (eds.), Mycotoxic fungi mycotoxins mycotoxicoses: An encyclopedic handbook. Volume 2. Marcel Dekker, Inc., New York, N.Y.

Mantle, P.G. 1978b. Ergotism in sheep. p. 207-213. In: T.D. Wyllie, and L.G. Morehouse (eds.), Mycotoxic fungi mycotoxins mycotoxicoses: An encyclopedic handbook. Vol. 2. Marcel Dekker, Inc., New York, N.Y. 
Marten, G.C. 1973. Alkaloids in reed canarygrass. p. 15-31. In: A.G. Matches (ed.) Antiquality components of forages. Special Publ. No. 4. Crop Sci. Soc. Amer. Madison, Wisc.

Marten, G.C., R.M. Jordan, and A.W Hovin. 1976. Biological significance of reed canarygrass alkaloids and associated palatability variation to grazing sheep and cattle. Agron. J. 68:909-914.

Marten, G.C., R.M. Jordan, and A.W. Hovin. 1981. Improved lamb performance associated with breeding for alkaloid reduction in reed canarygrass. Crop Sci. 21:295-298.

Marum, P.A., A.W. Hovin, and G.C. Marten. 1979. Inheritance of three groups of indole alkaloids in reed canarygrass. Crop Sci. 19:539-544.

McCann, J.S., G.L. Heusner, H.E. Amos, and D.L. Thompson, Jr. 1992a. Growth rate, diet digestibility, and serum prolactin of yearling horses fed non-infected and infected tall fescue hay. J. Equine Vet. Sci 12:240-243.

McCann, J.S., AB. Caudle, F.N. Thompson, J.A. Stuedemann, G.L. Heusner, and D.L. Thompson, Jr. 1992b. Influence of endophyte-infected tall fescue on serum prolactin and progesterone in gravid mares. J. Anim. Sci. 70:217-223.

McIntosh, G.H., R. Rac, and MR. Thomas. 1967. Toxicity of parasitised Wimmera ryegrass, Lolium rigidum, for sheep and cattle. Aust. Vet. J. 43:349-353.

McKay, A.C. and J.T. Riley. 1993. Sampling ryegrass to assess the risk of annual ryegrass toxicity. Aust. Vet. J. 7:241-243.

Merigliano, M.F. and P. Lesica. 1998. The native status of reed canarygrass (Phlaris arundinacea L.) in the inland northwest, USA. Natural Area J. 18:223-230.

Mizinga, K.M., F.N. Thompson, J.A. Stuedemann, and G.L. Edwards. 1993. Neural dopamine $\mathrm{D}_{2}$ receptors in rats fed endophyte-infected fescue seed. Drug and Chem. Toxicol. 16:307-319.

Mizinga, K.M., F.N. Thompson, JA. Stuedemann, and T.E. Kiser. 1992. Effects of feeding diets containing endophyte-infected fescue seed on luteinizing hormone secretion in postpartum beef cows and in cycling heifers and cows. J. Anim. Sci. 70:3483-3489.

Monroe, J.L., D.L. Cross, L.H. Hudson, D.M. Henricks, SW. Kennedy, and W.C. Bridges, Jr. 1988. Effect of selenium and endophyte-contaminated fescue on performance and reproduction in mares. J. Equine Vet. Sci. 8:148-153.

Mortimer, P.H. and M.E. di Menna. 1985. Interactions of Lolium endophyte on pasture production and perennial ryegrass staggers disease. p. 149-158. In: J. Lacey (ed.), Trichothecenes and other cycotoxins. John Wiley \& Sons, New York, N.Y.

Moubarak AS., E.L. Piper, and C.P. West. 1993. Interaction of purified ergovaline from endophyte-infected tall fescue with the synaptosomal ATPase system. J. Agr. Food Chem. 41:407-409.
Moubarak, A.S., C.F. Rosenkrans, Jr., and Z.B. Johnson. 1998. Effect of ergotamine and ergonovine on the bovine liver mitochondrial ATPase system. Med. Sci. Res. 26:699-701.

Muller-Schweinitzer, E. and H. Weidmann. 1978. Basic pharmacological properties. p. 87-232. In: B. Berde and H.O. Schild (eds.), Ergot alkaloids and related compounds. Springer-Verlag, New York, N.Y.

Munday, B.L., I.M. Monkhouse, and R.T. Gallagher. 1985. Intoxication of horses by lolitrem B in ryegrass seed cleanings. Aust. Vet. J. 62:207.

Nasti, K.B., R.W. Rorie, S.P. Schmidt, R.L. Carson, D.A. Stringfellow, and C.H. Rahe. 1994. In vitro fertilization rate and development of bovine ova are affected by factors in seeds of endophyte-infected tall fescue. J. Anim. Sci. 72(Suppl. 1):283.

Nelson, L.R. and S.L. Ward. 1990. Presence of fungal endophyte in annual ryegrass. p. 41-43. In: R. Joost and S. Quisenbeny (eds.), Proc. Int'l Symp. on Acremoniumi grass interactions. Louisiana Agr. Exp. Sta. Press, Baton Louge, La.

Nickerson, M. 1970. Drugs inhibiting adrenergic nerves and structures innervated by them. p. 549-584. In: LS. Goodman and A. Gilmer (ed.), The Pharmacological Basis of Therapeutics, $4^{\text {th }}$ ed. The Macmillan Company, Collier-Macmillan Ltd., London, UK.

Nicholson, S.S., B.M. Olcott, E.A. Usenik, H.W. Casey, C.C. Brown, L.E. Urbatsch, SE. Turuquist, and S.C. Moore. 1989. Delayed phalaris grass toxicosis in sheep and cattle. J. Amer. Vet. Med. Assoc. 195:345-346.

Niklowitz, P. and K. Hoffmann. 1988. Pineal and pituitary involvement in the photoperiodic regulation of body weight, coat color and testicular size of the Djungarian Hamster, Phodopus sungorus. Biol. Reprod. 39:489-498

Nutting, D.F., E.A. Tolley, L.A. Toth, S.D. Ballard, and M.A. Brown. 1992. Serum amylase activity and calcium and magnesium concentrations in young cattle grazing fescue and bermuda grass pastures. Amer. J. Vet. Res. 53:834-839.

Oliver, J.W. 1997. Physiological manifestations of endophyte toxicosis in ruminant and laboratory species. p. 311-346. In: C.W. Bacon and N.S. Hill (eds.), Neotyphodium/grass interactions. Plenum Press, New York, N.Y

Oliver, J.W. and A.E. Schultze. 1997. Histologic lesions in cattle fed toxic tall fescue grass. Soc. of Tox. Annual Meeting, Abst. No. 234, p. 46.

Oliver, J.W., R.G. Powell, L.A. Abney, R.D. Lmnnabary, and R.J. Petroski. 1990. $\mathrm{N}$-acetyl loline-induced vasoconstriction of the lateral saphenous vein (cranial branch) of cattle. p. 239-243. In: Proc. of the mt. Symposium on Acremonium/grass interactions. Louisiana Agr. Exp. Sta., Baton, Rouge, La.
Oliver, J.W., A.E. Schultze, B.W. Rohrbach, H.A. Fribourg, T. Ingle, and J.C. Waller. 2000. Alterations in hemograms and serum biochemical analytes of steers after prolonged consumption of endophyte-infected tall fescue. J. Anim. Sci. 78:1029-1035.

Oliver, J.W., J.R. Strickland, J.C. Waller, H.A. Fribourg, R.D. Lmnnabary, and L.K. Abney. 1998. Endophytic fungal toxin effect on adrenergic receptors in lateral saphenous veins (cranial branch) of cattle grazing tall fescue. J. Anim. Sci. 76:2853-2856.

Ophel, K.M., A.F. Bird, and A. Kerr. 1993. Association of bacteriophage particles with toxin production by Clavibacter toxicus, the causal agent of annual ryegrass toxicity. Phytopathology 83:676-681.

Osborn, T.G., S.P. Schmidt, D.N. Marple, C.H. Rahe, and J.R. Steenstra. 1992. Effect of consuming fungus-infected and fungus-free tall fescue and ergotamine tartrate on selected physiological variables of cattle in environmentally controlled conditions. J. Anim. Sci. 70:2501-2509.

Osweiler, GD. 1981. Ergot (Gangrenous). p. 404-405. In: J.L. Howard (ed.), Current veterinary therapy, food animal practice. W.B. Saunders Co., Philadelphia, Penn.

Peters, C.W., K.N. Grigsby, C.G. Aldrich, J.A. Paterson, R.J. Lipsey, MS. Kerley, and G.B. Garner. 1992. Performance, forage utilization, and ergovaline consumption by beef cows grazing endophyte fungus-infected tall fescue, endophyte fungus-free tall fescue, or orchardgrass pastures. J. Anim. Sci. 70:1550-1561.

Porter, J.K. 1994. Chemical constituents of grass endophytes. Ch. 8, p. 103-123. In: C.W. Bacon and J.F. White, Jr. (eds), Biotechnology of Endophytic Fungi of Grasses. CRC Press, Boca Raton, Fla.

Porter, J.K. and F.N. Thompson, Jr. 1992. reproduction in livestock. J. Anim. Sci. 70:1594-1603.

Porter, J.K., C.W. Bacon, RD. Plattner, and R.F. Arrendale. 1987. Ergot peptide alkaloid spectra of claviceps-infected tall fescue, wheat, and barley. J. Agr. Food Chem. 35:359-361.

Porter, J.K., JA. Stuedemann, F.N. Thompson, Jr., and L.B. Lipham. 1990. Neuroendocrine measurements in steers grazed on endophyte-infected fescue. J. Anim. Sci. 68:3285-3292.

Prestidge, R.A. 1991. Susceptibility of Italian ryegrasses (Lolium multiflorum L.) to argentine stem weevil (Listronotus-bonariensiss (Kuschel)) feeding and oviposition. New Zealand J. Agr. Res. 34:119-125.

Prestidge, R.A. and R.T. Gallagher. 1988. Endophyte fungus confers resistance to ryegrass-Argentine Stem Weevil Larval Studies. Econ. Entomol. 13:429-435.

Purdy, C.W., NA. Cole, and JA. Stuedemann. 1989. The effect of fescue toxicosis on classical complement in yearling feedlot steers. J. Vet. Diagn. Invest. 1:87-89.

Putnam, M.R., D.I. Bransby, J. Schumacher, T.R. Boosinger, L. Bush, R.A. Shelby, J.T. Vaughan, D. Ball, and J. P. Brendemuehl. 1991. Effects of the fungal endophyte 
Acremonium coenophialum in fescue on pregnant mares and foal viability. Amer. J. Vet. Res. 52:2071-2074.

Rahe, C.H., S.P. Schmidt, J.L. Griffin, C.A. Maness, D.I. Bransby, D.A. Coleman, R.L. Carson, and D.A. Stringfellow. 1991. Embryo survival is reduced in heifers grazing Kentucky-3 1 tall fescue infected with Acremonium coenophialum. J. Anim. Sci. 69(Suppl. 1): 407.

Redmond, L.M., D.L. Cross, J.R. Strickland, and S.W. Kennedy. 1994. Efficacy of domperidone and sulpiride for fescue toxicosis in horses. Amer. J. Vet.Res. 55:722-729.

Read, J.C. and B.J. Camp. 1986. The effect of the fungal endophyte Acremonium coenophialum in tall fescue on animal performance, toxicity, and stand maintenance. Agron. J. 78:848-850.

Rhodes, M.T., J.A. Paterson, MS. Kerley, HE. Garner, and M.H. Laughlin. 1991 Reduced blood flow to preipheral and core body tissues in sheep and cattle induced by endophyte-infected tall fescue. J. Anim. Sci. 69:2033-2043

Rhorbach, B.W., EM. Green, J.W. Oliver, and J.F. Schneider. 1995. Aggregate risk study of exposure to endophyte-infested (Acremonium coenophialum) tall fescue as a risk factor for laminitis in horses. Amer. J. Vet. Res. 56:22-26.

Rice, R.L., D.J. Blodgett, G.G. Schurig, W.S. Swecker, J.P. Fontenot, V.G. Allen, and R.M. Akers. 1997. Evaluation of humora immune responses in cattle grazing endophyte-infected or endophyte-free fescue Vet. Immunol. and Immunopath. 59:285-291.

Riley, I.T. and K.M. Ophel. 1992. Clavibacter toxicus sp. nov., the bacterium responsible for annual ryegrass toxicity in Australia. Int J. Syst. Bacteriol. 42:64-68.

Robbins, J.E., J.K. Porter, and C.W. Bacon. 1986. Occurrence and clinical manifestations of ergot and fescue toxicosis. p. 61-74. In J.L. Richard and J.R. Thurston (eds.), Diagnosis of mycotoxicoses. Martinus Nijhoff Publishers, Dordrecht, Netherlands.

Saker, K.E., V.G. Allen, J. Kalnitsky, C.D. Thatcher, W.S. Sweckner, Jr., and J.P. Fontenot. 1998. Monocyte immune cell response and copper status in beef steers that grazed endophyte-infected tall fescue. J. Anim. Sci. 76:2694-2700.

Schmidt, S.P. and T.G. Osborn. 1993. Effects of endophyte-infected tall fescue on animal performance. Agr. Ecosys. Environ. 44:233-262.

Schmidt, S.P., D.A. Danilson, J.A. Holliman, H.W. Grimes, and W.B. Webster. 1986. Fescue fungus suppresses growth and reproduction in replacement beef heifers Highlights of Agr. Res. 33:15. Alabama Agr. Exp. Sta., Auburn Univ., Auburn, Ala

Schmidt, S.P., CS. Hoveland, E.M. Clark, N.D. Davis, L.A. Smith, H.W. Grimes, and J.L. Holliman. 1982. Association of an endophytic fungus with fescue toxicity in steers fed Kentucky 31 tall fescue seed or hay. J. Anim. Sci. 55:1259-1263.
Schmidt, S.P., C.C. King, J.F. Pederson, CS. Hoveland, L.A. Smith, H.W. Grimes, and J.L. Holliman. 1984. Fungus-infected fescue pastures reduce cow-calf performance. Alabama Agr. Exp. Sta. Highlights Agr. Res. 31(3): 17

Schneider, D.J., C.O. Miles, I. Garthwaite, A. Van Halderen, J.C. Wessels, and H.J. Lategan. 1996. First report of field outbreaks of ergot-alkaloid toxicity in South Africa. Onderstepoort J. Vet. Res. 62:97-108.

Schultze, A.E., B.W. Rohrbach, H.A. Fribourg, J.C. Waller, and J.W. Oliver. 1999. Alterations in bovine serum biochemistry profiles associated with prolonged consumption of endophyte-infected tall fescue. Vet. and Hum. Toxicol. 41:133-139.

Sheaffer, C.C. and G.C. Marten. 1995. Reed canarygrass. p. 335-343. In: R.F. Barnes, D.A. Miller, and C.J. Nelson (eds.). Forages. Volume I: An introduction to grassland agriculture. Iowa State Univ. Press, Ames, Ia.

Shelby, RA. and L.W. Dalrymple. 1987. Incidence and distribution of the tall fescue endophyte in the United States. Plant Disease 71:783-786.

Siegel, M.R., G.C.M. Latch, L.P. Bush, N.F. Fannin, D.D. Rowen, B.A. Tapper, and C.W. Bacon. 1991. Alkaloids and insecticidal activity of grasses infected with different endophytes. J. Chem. Ecol. 16:3301-3315.

Simons, A.B. and G.C. Marten. 1971. Relationship of indole alkaloids to palatability of Phalaris arundinacea L. Agron. J. 63:915-919.

Skarland, AS. and O.O. Thomas. 1972. Effect of ergot on performance of beef heifers. Proc. West. Sect. Amer. Soc. Anim. Sci. 23:426-431.

Solomons, R.N., J.W. Oliver, and R.D. Linnabary. 1989. Dorsal pedal vein of cattle: Reactivity to selected alkaloids associated with Acremonium coenophialum-infected fescue grass. Amer. J. Vet. Res. 50:235-238.

Spiers, D.E., Q. Zhang, PA. Eichen, G.E. Rottinghaus, G.B. Garner, and M.R. Ellersieck. 1995. Temperature-dependent responses of rats to ergovaline derived from endophyte-infected tall fescue. J. Anim. Sci. 73:1954-1961.

Steen, W.W., N. Gay, J.A. Boling, R.C. Buckner, L.P. Bush, and G. Lacefield. 1979. Evaluation of Kentucky 31, G1 -306, G1 -307 and Kenhy tall fescue as pasture for yearling steers. II. Growth, physiological response and plasma constituents of yearling steers. J. Anim. Sci. 48:618-623.

Stidham, W.D., C.J. Brown, LB. Daniels, E.L. Piper, and H.E. Fetherstone. 1982. Toxic fescue linked to reduced milk output in ewes. Arkansas Farm Res. 3 1(6):9.

Stoszek, M.J., J.E. Oldfield, G.E. Carter, and P.H. Weswig. 1979. Effect of tall fescue and quackgrass on copper metabolism and weight gains of beef cattle. J. Anim. Sci. 48:893-899.

Strahan, S.R., R.W. Hemken, JA. Jackson, Jr., R.C. Buckner, L.P. Bush, and M.R. Siegel. 1987. Performance of lactating dairy cows fed tall fescue forage. J. Dairy Sci. 70:1228-1234.
Strickland, J.R., E.M. Bailey, L.K. Abney, and J.W. Oliver. 1996. Assessment of the mitogenic potential of the alkaloids produced by endophyte (Acremonium coenophialum) infected tall fescue (Festuca arundinacea) on bovine vascular smooth muscle in vitro. J. Anim. Sci. 74:1664-1671.

Stuedemann, J.A. and C.S. Hoveland. 1988. Fescue endophyte: History and impact on animal agriculture. J. Prod. Agr. 1:39-44.

Stuedemann, J.A. and F.N. Thompson. 1993. Management strategies and potential opportunities to reduce the effects of endophyte-infested tall fescue on animal performance. p. 103-114. In: D.E. Hume, G.C.M. Latch, and H.S. Easton (eds.), Proc. Second Internat. Symp. On Acremonium/grass interactions: Plenary papers. AgResearch, Grassl. Res. Centre, New Zealand.

Stuedemann, J.A., D.L. Breedlove, K.R. Pond, D.P. Belesky, L.P. Tate, Jr, F.N. Thompson, and SR. Wilkinson. 1989. Effect of endophyte (Acremonium coenophialum) infection of tall fescue and paddock exchange on intake and performance of grazing steers. p. 1243-1244. Proc. XVI Intern. Grassl. Congress, Nice, France.

Stuedemann, JA., T.S. Rumsey, J. Bond, S.R. Wilkinson, L.P. Bush, D.J. Williams, and AB. Caudle. 1985a. Association of blood cholesterol with occurrence of fat necrosis in cows and tall fescue summer toxicosis in steers. Amer. J. Vet. Res. 46:1990-1995.

Stuedemann, JA., SR. Wilkinson, D.P. Belesky, O.J. Devine, DL. Breedlove, F.N. Thompson, C.S. Hoveland, H. Ciordia, and W.E. Townsend. 1985b. Utilization and management of endophyte-infested tall fescue: Effects on steer performance and behavior. p. 17-20. In: J.D. Miller (ed.), Proc. $41^{\text {st }}$ South. Pasture Forage Comp. Imp. Conf., Raleigh, N.C. May 20-22.

Stuedemann, J.A., S.R. Wilkinson, D.P. Belesky, F.N. Thompson, D.L. Breedlove, D.M. Hildreth, H. Ciordia, A.H. Parks, C.S. Hoveland, and J. Huang. 1993. Effect of tiller endophyte infection frequency and nitogen fertilization rate of tall fescue on steer performance over nine seasons of grazing. p. 1386-1387. In: J.R. Crush, M.J. Baker, R.W. Brougham, and J. Hodgson (eds.), Proc XVII Internat. Grassl. Congr. New Zealand and Australia, 8-12 Feb. 1993.

Taylor, W. 1993. Effect of removal time on reproductive performance in pregnant mares grazing endophyte-infected fescue. M.S. Thesis, Clemson Univ., Clemson, S.C.

Thompson, F.N., JA. Stuedemann, J.L. Sartin, D.P. Belesky, and O.J. Devine. 1987. Selected hormonal changes with summer fescue toxicosis. J. Anim. Sci. 65:727-733.

Thompson, W.S., W.W. McClure, and M. Landowne. 1950. Prolonged vasoconstriction due to ergotamine tartrate. Archiv. Intern. Med. 85:691-698. 
Tolley, E.A., MA. Brown, and D.F. Nutting. 1990. Gender and breed differences in serum cholesterol of young cattle grazing fescue and bermuda pastures. p. 282-285. In: S.S Quisenberry \& RE. Joost (eds), Proceedings Internat. Symp. on Acremonium/Grass Interactions. Louisiana Agr. Exp. Sta., Baton Rouge, La.

Tucker, C.A., R.E. Morrow, JR. Gerrish, C.J. Nelson, G.B. Garner, V.E. Jacobs, W.G. Hires, J.J. Shinkle, and JR. Forwood. 1989. Forage systems for beef cattle: effect of winter supplementation and forage system on reproductive performance of cows. J. Prod. Agr. 2:217-221.

Vogel, P. and M.G. McGarth. 1986. Corynetoxins are not detoxicated by in vitro fermentation in ovine rumen fluid. Aust. J. Agr. Res. 37:523-526.

Washburn, S.P. and J.T. Green, Jr. 1991. Performance in replacement beef heifers on endophyte-infected fescue pastures. In: Proc. $40^{\text {th }}$ Annu. Conf. North Carolina Cattleman's Assoc. February 25-26, North Carolina State Univ., Raleigh, N.C.
Washburn, S.P., J.T. Green, Jr., and B.H. Johnson. 1989. Effects of endophyte presence in tall fescue on growth, puberty, and conception in Angus heifers. In: Proc. Tall Fescue Toxicoses Workshop, SRIEG-8. November 13-14, Atlanta, Ga, p. 80.

West, C.P., E. Izekor, K.E. Turner, and A.A. Elmi. 1993. Endophyte effects on growth and persistence of tall fescue along a water-supply gradient. Agron. J. 85:264-270.

Westendorf, M.L., G.E. Mitchell, Jr., R.E. Tucker, L.P. Bush, R.J. Petroski, and R.G. Powell. 1993. In vitro and in vivo ruminal and physiological responses to endophyteinfected tall fescue. J. Dairy Sci. 76:555-563.

Wiltbank, J.N., W.W. Rowden, J.E. Ingalls, and D.R. Zimmrman. 1964. Influence of postpartum energy level on reproductive performance of Hereford restricted in energy intake prior to calving. J. Anim. Sci. 23(Suppl 4):1049-1053.

Woods, D.L., A.W. Hovin, and G.C. Marten. 1979. Seasonal variation of hordenine and gramine concentrations and their heritability in reed canarygrass. Crop Sci. 19:853-857.
Woods, A.J., J.B. Jones, and PG. Mantle. 1966. An outbreak of dangerous ergotism in cattle. Vet. Res. 78:742-749.

Yates, S.G. 1983. Tall fescue toxins. p. 249-273. In: M. Rechcigl, Jr. (ed). Handbook of Naturally Occurring Food Toxicants. CRC Press, Boca Raton, Fla.

Yates, S.G., J.A. Rothfus, G.B. Garner, and C.N. Cornell. 1979. Video-thermometry for assay of fescue foot in cattle. Amer. J. Vet. Res. 40:1192-1196.

Zanzalari, K.P., R.N. Heitmann, J.B. McLaren, and H.A. Fribourg. 1989. Effects of endophyte-infected fescue and cimetidine on respiration rates, rectal temperatures and hepatic mixed function oxidase activity as measured by hepatic antipyrine metabolism in sheep. J. Anim. Sci. 67:3370-3378. 